\title{
Effects of Ligands, Cluster Size, and Charge State in Gas-Phase Catalysis: A Happy Marriage of Experimental and Computational Studies
}

\author{
Maria Schlangen $\cdot$ Helmut Schwarz
}

Received: 10 August 2012/ Accepted: 12 August 2012/Published online: 5 September 2012

(C) The Author(s) 2012. This article is published with open access at Springerlink.com

\begin{abstract}
We present selected examples of gas-phase reactions which are of timely interest for the activation of small molecules. Due to the very nature of the experiments, detailed insight in the active site of catalysts is provided and-in combination with computational chemistrymechanistic aspects of as well as the elementary steps involved in the making and breaking of chemical bonds are revealed.
\end{abstract}

Keywords Bond activation · Catalysis · Transition metals · Reaction mechanisms $\cdot$ Elementary steps

\section{Introduction}

Since the seminal publication of Kappes and Staley in 1981 on "Gas-Phase Oxidation by Transition-Metal Cations" [1], various aspects of this topical problem have been addressed in numerous reviews [2-25]. The enormous interest is due to the fact that gas-phase studies on 'isolated' reactants provide an ideal arena for probing experimentally the energetics and kinetics of a chemical reaction in an unperturbed environment at a strictly molecular level without being obscured by difficult-to-control or poorly

M. Schlangen $(\square) \cdot$ H. Schwarz $(\square)$

Institut für Chemie, Technische Universität Berlin, 10623 Berlin,

Germany

e-mail: maria.schlangen@mail.chem.tu-berlin.de

H. Schwarz

e-mail: helmut.schwarz@mail.chem.tu-berlin.de

H. Schwarz

Faculty of Science, King Abdulaziz University, Jeddah 21589,

Saudi Arabia understood solvation, aggregation, counterions and other effects, thus providing an opportunity to explore the concept of single-site catalysts directly [26-33]. Further, in these experiments reactive intermediates can be characterized in detail, mechanisms uncovered, and questions addressed on how factors such as cluster size and dimensionality, stoichiometry, oxidation state, degree of coordinative saturation, aggregation, or charge state affect the outcome of a chemical process. Active or single-sites in heterogeneous catalysis are usually rather ill-defined and often characterized by dangling bonds, kinks, steps, defects, or nano-sized particles; probing them experimentally is all but trivial $[31,32,34]$ and their identification constitutes one of the intellectual cornerstones in contemporary catalysis. As 'naked' gas-phase species are, in general, much more reactive than their condensed-phase counterparts, these studies will, in principle, of course never account for the precise kinetic and mechanistic details which prevail at a surface or in the condensed phase. Yet, complemented by appropriate computational studies, gas-phase experiments have proved meaningful, on the ground that they permit a systematic approach to address the above mentioned questions and provide a conceptual framework. The DEGUSSA process, that is the platinum-mediated coupling of $\mathrm{CH}_{4}$ and $\mathrm{NH}_{3}$ to generate HCN [35], may serve as a good example. Mass-spectrometry based experiments $[36,37]$ suggested (i) the key role of $\mathrm{CH}_{2} \mathrm{NH}$ as a crucial transient, and (ii) the advantage of using a bimetallic rather than a pure platinum-based catalysts for the $\mathrm{C}-\mathrm{N}$ coupling step in competition with undesired soot formation; the existence of $\mathrm{CH}_{2} \mathrm{NH}$ was later confirmed by in situ photoionization studies [38] and currently used catalysts contain silver-platinum alloys. Obviously, each and every information and insight that help to optimize or improve the often trial-and-error based 
strategies on catalyst developments [39] are highly welcome.

In this invited perspective, we focus on selected aspects of four gas-phase catalytic reactions all of which are mediated by ionic species under thermal conditions; they encompass (i) the coupling of carbon-carbon bonds, (ii) the $\mathrm{CO} \rightarrow \mathrm{CO}_{2}$ conversion at ambient conditions, (iii) the activation of hydrocarbons, and (iv) the selective oxidation of methanol to formaldehyde.

While we will refrain from describing the various experimental techniques (which are available from the references given), we will rather focus on the elucidation of the often intriguing mechanisms.

\section{Metal-mediated Formation of Carbon-Carbon Bonds}

Cyclooligomerizations of unsaturated hydrocarbons, in particular assembling them to form benzene, are versatile reactions for the synthesis of aromatic compounds [40]. Although these reactions are quite exothermic, they are usually hampered by large barriers if non-activated hydrocarbons are employed. Transition-metal complexes have been found to facilitate these processes in the condensed phase, and even single $\mathrm{Ag}, \mathrm{Rh}$, and $\mathrm{Pt}$ atoms supported on a $\mathrm{MgO}(001)$ surface were found to bring about acetylene trimerization at ambient conditions [41]. Also in the gas phase, certain 'bare' transition-metal cations $\mathrm{M}^{+}$ affect these cyclization processes, and the catalytic reactions are often accompanied by dehydrogenation steps. The most classical example of the stepwise route [42] correspond to the dehydrogenative gas-phase trimerization of $\mathrm{C}_{2} \mathrm{H}_{4}$ by atomic $\mathrm{W}^{+}$[43], $\mathrm{U}^{+}$[44], $\mathrm{Fe}^{+}$[45-47], or $\mathrm{Fe}_{n}{ }^{+}$ cluster [48-51]. The unique reactivity of the $\mathrm{Fe}_{4}{ }^{+}$cluster, in comparison to other cluster sizes of iron or the complete absence of reactivity of $\mathrm{Ni}_{4}{ }^{+}$towards $\mathrm{C}_{2} \mathrm{H}_{4}$ already illustrates the often-noted non-scalability of cluster properties-in fact, each atom counts [11]!

As depicted in Fig. 1, the oligomerization sequence commences with the formation of a cationic metal-ethyne complex. In the next, often rate-limiting step, the $\mathrm{M}\left(\mathrm{C}_{2} \mathrm{H}_{2}\right)^{+}$intermediate brings about dehydrogenation of a further ethene molecule to produce $\mathrm{M}\left(\mathrm{C}_{4} \mathrm{H}_{4}\right)^{+}$; for some metal cations $\mathrm{M}^{+}$, for example $\mathrm{U}^{+}$, there is experimental evidence that this complex contains a $\mathrm{C}_{4}$ unit rather than two separate $\mathrm{C}_{2} \mathrm{H}_{2}$ ligands [44], while in the $\mathrm{M}\left(\mathrm{C}_{4} \mathrm{H}_{4}\right)^{+}$ complexes, generated by association of atomic $\mathrm{Fe}^{+}$or $\mathrm{Ni}^{+}$ with $\mathrm{C}_{2} \mathrm{H}_{2}$, the preferred structure corresponds to $\mathrm{M}\left(\mathrm{C}_{2} \mathrm{H}_{2}\right)_{2}{ }^{+}[44,52]$. Addition of a third $\mathrm{C}_{2} \mathrm{H}_{4}$ molecule results in the formation of a metal-benzene complex as evidenced by numerous experimental findings. Although the process $\mathrm{M}\left(\mathrm{C}_{4} \mathrm{H}_{4}\right)^{+}+\mathrm{C}_{2} \mathrm{H}_{4} \rightarrow \mathrm{M}\left(\mathrm{C}_{6} \mathrm{H}_{6}\right)^{+}+\mathrm{H}_{2}$ is rather exothermic, the heat of reaction liberated is usually not sufficient to overcome the quite significant bond dissociation energy of $\mathrm{M}^{+}-\mathrm{C}_{6} \mathrm{H}_{6}$ and to release benzene from the catalyst; as a consequence, regeneration of the active catalyst $\mathrm{M}^{+}$is not observed under strictly thermal conditions and can only be achieved by external energy supply in form of e.g. collisional induced dissociation (CID). Of course, in a 'perfect' catalytic cycle the catalyst should be regenerated in the reaction without additional supply of energy. This is conveniently achieved in gas-phase experiments by employing 'high-energy' reactants [42, 45, 46]. For example, substituting $\mathrm{C}_{2} \mathrm{H}_{2}$ for $\mathrm{C}_{2} \mathrm{H}_{4}$ as a reactant increases the exothermicity of the final step $\mathrm{M}\left(\mathrm{C}_{4} \mathrm{H}_{4}\right)^{+}+\mathrm{C}_{2} \mathrm{H}_{2} \rightarrow \mathrm{M}^{+}+\mathrm{C}_{6} \mathrm{H}_{6}$ by approximately the heat of dehydrogenation of $\mathrm{C}_{2} \mathrm{H}_{4}$, i.e. $42 \mathrm{kcal} \mathrm{mol}^{-1}$. As this additional reaction energy is stored completely in the isolated encounter complex, spontaneous detachment of $\mathrm{C}_{6} \mathrm{H}_{6}$ is possible. While these gas-phase studies have certainly uncovered interesting mechanistic details, there is no doubt that many important features, e.g. the particular role of spin states or that of the geometric structures of the catalytically active metal-ion clusters remain to be resolved as indicated by a comprehensive DFT study of the $\mathrm{Fe}_{n}{ }^{0,+}$ / $\left(\mathrm{C}_{2} \mathrm{H}_{2}\right)_{m}$ systems $(n=1-4 ; m=2,3)$ [47].

An entirely different type of carbon-carbon coupling has been reported for the oxidative dimerization of methane, Eq. (1); this large-scale conversion is conventionally performed in a heterogeneous process at temperatures above $650{ }^{\circ} \mathrm{C}[53,54]$ and the challenge is to suggest a catalyst that operates under more benign conditions.

$2 \mathrm{CH}_{4}+\mathrm{O}_{2} \rightarrow \mathrm{C}_{2} \mathrm{H}_{4}+2 \mathrm{H}_{2} \mathrm{O}$

While some intriguing mechanistic aspects of the rate limiting $\mathrm{C}-\mathrm{H}$ bond activation step in the metal-oxide mediated methane coupling will be described in Section 4, here we mention a few notable cluster-size and temperature effects which were reported recently by Lang et al. [55-57]. In contrast to atomic ground-state $\mathrm{Au}^{+}\left({ }^{1} S_{0}\right)$,

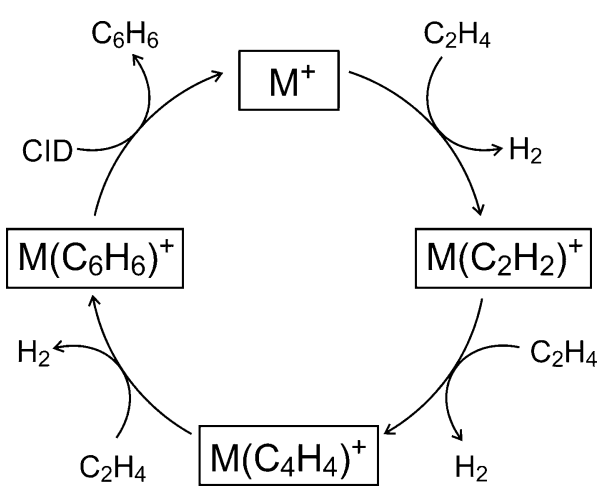

Fig. 1 Dehydrogenative oligomerization of $\mathrm{C}_{2} \mathrm{H}_{4}$ and formation of benzene by consecutive gas-phase ion-molecule reactions (adapted from Ref. [42]) 
which is unreactive towards $\mathrm{CH}_{4}$ at ambient conditions [58], isolated $\mathrm{Au}_{2}{ }^{+}$clusters bring about $\mathrm{C}-\mathrm{C}$ coupling of methane to yield ethene in full thermal catalytic cycles, and for this particular cluster size the chemoselectivity in terms of product formation depends crucially on the temperature and the absence or presence of oxygen. For the metal clusters of palladium and platinum, both varying in size, a much lower selectivity has been reported [56, 59-62], and for the $\mathrm{Au}_{2}{ }^{+} / \mathrm{CH}_{4} / \mathrm{O}_{2}$ system, detailed experimental investigations, complemented by first-principle simulations, revealed the coupled catalytic cycles shown in Fig. 2.

In the absence of $\mathrm{O}_{2}$ or at higher temperature, at which $\mathrm{O}_{2}$ does not readily adsorb on $\mathrm{Au}_{2}{ }^{+}$, the mass-selected $\mathrm{Au}_{2}{ }^{+}$cluster reacts with a first $\mathrm{CH}_{4}$ molecule to yield collisionally stabilized $\mathrm{Au}_{2}\left(\mathrm{CH}_{4}\right)^{+} ; \mathrm{C}-\mathrm{H}$ bond activation and dehydrogenation do not take place but require the adsorption of a second methane molecule to form $\mathrm{Au}_{2}\left(\mathrm{C}_{2} \mathrm{H}_{4}\right)^{+}$and $2 \mathrm{H}_{2}$. Obviously, these processes are the outcome of a co-operative action of both ligands. Oxidative coupling is observed only at temperatures $>250 \mathrm{~K}$, and the energy-demanding release of $\mathrm{C}_{2} \mathrm{H}_{4}$ from $\mathrm{Au}_{2}\left(\mathrm{C}_{2} \mathrm{H}_{4}\right)^{+}$ requires both higher temperatures $(\sim 300 \mathrm{~K})$ as well as the adsorption of yet another molecule of $\mathrm{CH}_{4}$. It is this very step that closes cycle II and regenerates the active catalyst $\mathrm{Au}_{2}\left(\mathrm{CH}_{4}\right)^{+}$. In the presence of $\mathrm{O}_{2}$ and at lower temperature $(210 \mathrm{~K})$ considerable changes in the product distribution take place. Two new, oxygen-containing products, $\mathrm{Au}_{2}\left(\mathrm{CH}_{4}\right)_{2} \mathrm{O}_{2}{ }^{+}$and $\mathrm{Au}_{2}\left(\mathrm{C}_{3} \mathrm{H}_{8} \mathrm{O}_{2}\right)^{+}$, are formed at the expense of $\mathrm{Au}_{2}\left(\mathrm{CH}_{4}\right)^{+}$and $\mathrm{Au}_{2}\left(\mathrm{C}_{2} \mathrm{H}_{4}\right)^{+}$. The kinetic

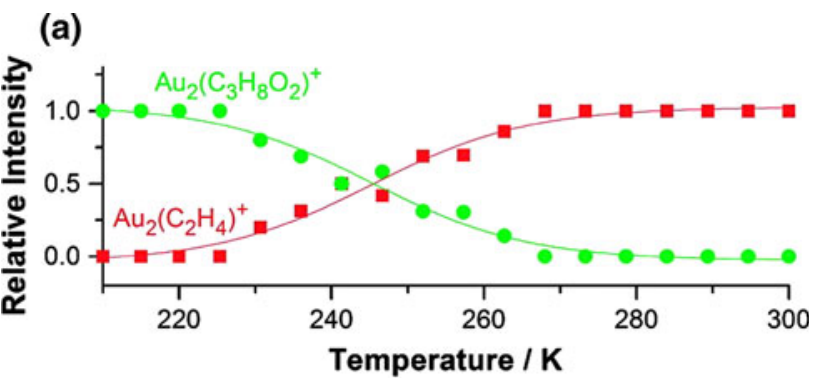

(b)

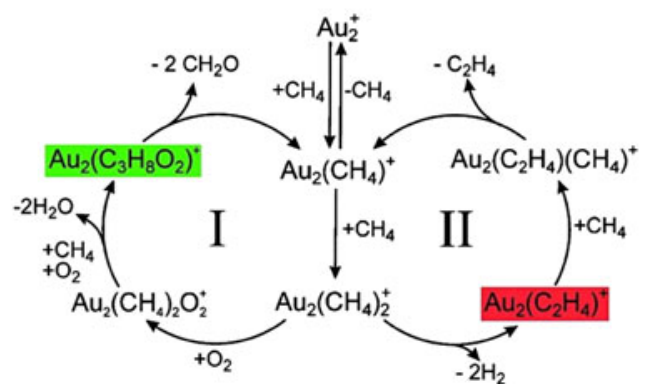

Fig. 2 a Relative intensities of the products $\mathrm{Au}_{2}\left(\mathrm{C}_{2} \mathrm{H}_{4}\right)^{+}$and $\mathrm{Au}_{2}\left(\mathrm{C}_{3} \mathrm{H}_{8} \mathrm{O}_{2}\right)^{+}$as a function of temperature in the system $\mathrm{Au}_{2}{ }^{+}$/ $\mathrm{CH}_{4}(p=0.05 \mathrm{~Pa}) / \mathrm{O}_{2}(p=0.10 \mathrm{~Pa}) ; \mathbf{b}$ coupled catalytic cycles for the temperature-tunable formations of $\mathrm{CH}_{2} \mathrm{O}$ and $\mathrm{C}_{2} \mathrm{H}_{4}$ from $\mathrm{CH}_{4}$ (adapted from Ref. [57]) analyses in combination with labeling experiments and computational studies suggest the catalytic formation of formaldehyde according to cycle I and Eq. (2). As shown recently in a different context, a stoichiometric, direct conversion of $\mathrm{CH}_{4}$ to $\mathrm{CH}_{2} \mathrm{O}$ at room temperature can also be achieved by using $\mathrm{Al}_{2} \mathrm{O}_{3}{ }^{+}$[63].

$2 \mathrm{CH}_{4}+2 \mathrm{O}_{2} \rightarrow 2 \mathrm{CH}_{2} \mathrm{O}+2 \mathrm{H}_{2} \mathrm{O}$

\section{Low-temperature, Catalytic Oxidation of CO}

Catalytic conversion of harmful gases, produced in fossilfuel combustion, such as $\mathrm{CO}$ or the oxides of nitrogen, into nitrogen and carbon dioxide, is of utmost importance both environmentally and economically. While these redox reactions are exothermic, for example $\Delta_{\mathrm{r}} H=$ $-87.3 \mathrm{kcal} \mathrm{mol}^{-1}$ for the process $\mathrm{N}_{2} \mathrm{O}+\mathrm{CO} \rightarrow \mathrm{N}_{2}+$ $\mathrm{CO}_{2}$, they do not occur directly to any measurable extent at either room or elevated temperatures due to high barriers exceeding $47 \mathrm{kcal} \mathrm{mol}^{-1}$ for the $\mathrm{N}_{2} \mathrm{O} / \mathrm{CO}$ couple [64]. Catalysts are required to reduce these barriers, and the first example of a homogeneous catalysis in the gas phase in which atomic transition-metal cations bring about efficient $\mathrm{N}_{2} \mathrm{O}$ reduction by $\mathrm{CO}$ was reported by Kappes and Staley as early as 1981 [1]. Later, numerous other atomic maingroup and transition-metal cations have been tested as catalysts [64-68]. Out of 59 atomic cations investigated, 26 systems for the catalysis of O-atom transport were shown to lie within the 'thermodynamic window of opportunity' [11] defined by the oxygen affinities $(O A)$ of $\mathrm{N}_{2}$ and $\mathrm{CO}$, with $O A\left(\mathrm{~N}_{2}\right)=40$ and $O A(\mathrm{CO})=127 \mathrm{kcal} \mathrm{mol}^{-1}$. Catalytic activity, however, was observed with only ten atomic cations, namely $\mathrm{Ca}^{+}, \mathrm{Fe}^{+}, \mathrm{Ge}^{+}, \mathrm{Sr}^{+}, \mathrm{Ba}^{+}, \mathrm{Os}^{+}, \mathrm{Ir}^{+}, \mathrm{Pt}^{+}$, $\mathrm{Eu}^{+}$, and $\mathrm{Y}^{+}$. The remaining 16 cations, which meet the thermodynamic criteria for oxygen-atom transport $\left(\mathrm{Cr}^{+}\right.$, $\mathrm{Mn}^{+}, \mathrm{Co}^{+}, \mathrm{Ni}^{+}, \mathrm{Cu}^{+}, \mathrm{Se}^{+}, \mathrm{Mo}^{+}, \mathrm{Rn}^{+}, \mathrm{Rh}^{+}, \mathrm{Sn}^{+}, \mathrm{Te}^{+}$, $\mathrm{Re}^{+}, \mathrm{Pb}^{+}, \mathrm{Bi}^{+}, \mathrm{Tm}^{+}$, and $\mathrm{Lu}^{+}$), reacted too slowly during either the formation of $\mathrm{MO}^{+}$or its reduction by $\mathrm{CO}$. As shown earlier [69], this is due to a kinetic barrier resulting from an inefficient, spin-orbit coupling mediated curve crossing that is required for the change in multiplicities [9].

Metal-mediated, catalytic gas-phase oxidation of $\mathrm{CO}$ by nitrogen oxides is not confined to $\mathrm{N}_{2} \mathrm{O}$ as demonstrated by Bohme and co-workers [70]. Also $\mathrm{NO}$ and $\mathrm{NO}_{2}$ can be reduced, and taken together, these three systems constitute rare examples of metal-cation catalyzed reductions of $\mathrm{NO}_{2}$, $\mathrm{NO}$, and $\mathrm{N}_{2} \mathrm{O}$ coupled with the formation of an $\mathrm{N}-\mathrm{N}$ bond during the termolecular reductive dimerization of NO. As shown in Fig. 3, overall $\mathrm{NO}_{2}$ is reduced by $\mathrm{CO}$ to $\mathrm{N}_{2}$ catalyzed efficiently by any of the three atomic metal cations $\mathrm{M}^{+}(\mathrm{M}=\mathrm{Fe}, \mathrm{Os}, \mathrm{Ir})$.

In the context of 'catalyst poisoning', studies with platinum clusters revealed remarkable effects of both the 


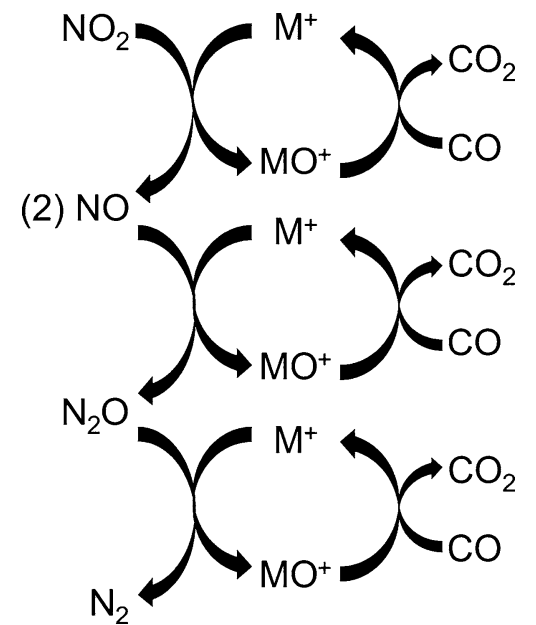

Fig. 3 Catalytic cycles for the room-temperature homogeneous reduction of nitrogen oxides by $\mathrm{CO}$, mediated by the atomic transition-metal cations $\mathrm{Fe}^{+}, \mathrm{Os}^{+}$, and $\mathrm{Ir}^{+}$(adapted from Ref. [70])

cluster size and the charge state for the $\mathrm{CO} / \mathrm{N}_{2} \mathrm{O}$ couple [71-73]. For example, for the $\mathrm{Pt}_{7}{ }^{+}$cluster, the active species in the redox process are $\mathrm{Pt}_{7}{ }^{+}, \mathrm{Pt}_{7} \mathrm{O}^{+}, \mathrm{Pt}_{7} \mathrm{O}_{2}{ }^{+}$, and $\mathrm{Pt}_{7} \mathrm{CO}^{+}$with a turnover number $>500$ in their thermal reaction with $\mathrm{CO}$. Adsorption of more than one $\mathrm{CO}$ molecule to the $\mathrm{Pt}_{7}{ }^{+}$cluster, however, completely quenches the catalytic activity, so that an elevated $\mathrm{CO}$ partial pressure has to be avoided [71]. Pronounced charge-state effects were reported for the $\mathrm{Pt}_{4}{ }^{+-}$clusters, which are known as the least reactive for the cationic and the most reactive one for anionic platinum clusters [60, 72, 74]. Also for the latter, the catalytic activity terminates as soon as two or more CO molecules are adsorbed on the cluster. The enormous reactivity differences for the anionic versus cationic $\mathrm{Pt}_{4}$ cluster ions have been addressed in theoretical studies. Some of the differences are due to geometrical features showing a near planar anion and a structurally distorted tetrahedral cation. The former provides significantly stronger bonds than $\mathrm{Pt}_{4}{ }^{+}$with both reactants $\mathrm{N}_{2} \mathrm{O}$ and $\mathrm{CO}$ [72]. In addition, for the $\mathrm{Pt}_{4}{ }^{+} / \mathrm{CO} / \mathrm{N}_{2} \mathrm{O}$ system there are kinetic barriers for both the doublet and quartet spin states that prevent the reaction to occur under thermal conditions [73].

More recently, the redox-features of heteronuclear metal-oxide clusters were exploited to bring about catalytic oxidation of $\mathrm{CO}$ by $\mathrm{N}_{2} \mathrm{O}$ at room temperature [75], and the bimetallic oxide cluster couple $\mathrm{AlVO}_{3}{ }^{+} / \mathrm{AlVO}_{4}{ }^{+}$may serve as a good example. As shown in Fig. $4, \mathrm{AlVO}_{4}{ }^{+}$in the presence of $\mathrm{CO}$ is reduced to $\mathrm{AlVO}_{3}{ }^{+}$, and if $\mathrm{N}_{2} \mathrm{O}$ is added, the reverse reaction occurs. Both processes are clean and proceed with efficiencies of 59 and $65 \%$ relative to the collision rate, respectively. As no by-products are formed, the turnover number of the catalytic cycle is principally infinite but in reality limited by side reactions
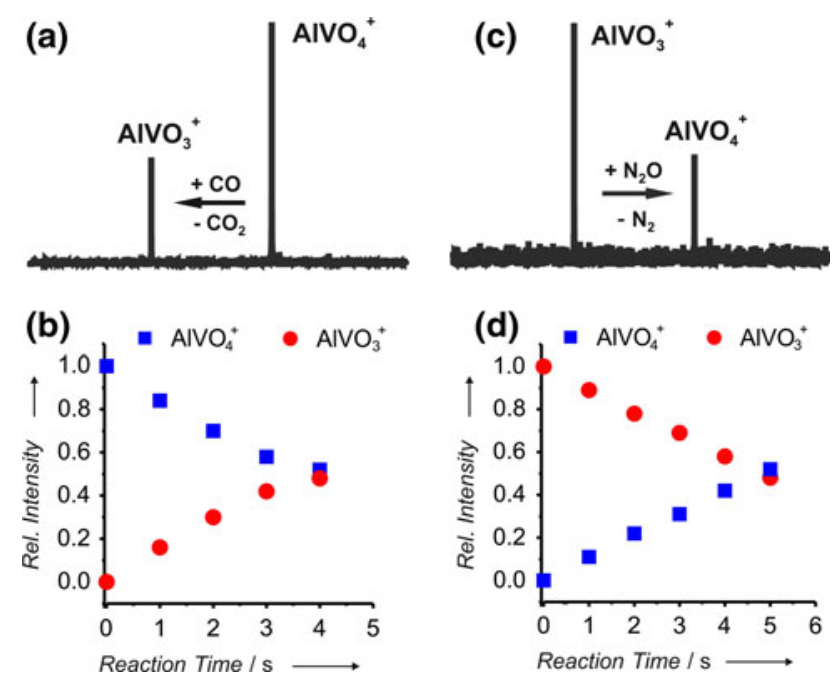

Fig. 4 Fourier-transform ion-cyclotron resonance (FT-ICR) mass spectra showing the thermal reactions of $\mathrm{a} \mathrm{AlVO}_{4}{ }^{+}$with $\mathrm{CO}(t=3 \mathrm{~s})$ and $\mathbf{c} \mathrm{AlVO}_{3}{ }^{+}$with $\mathrm{N}_{2} \mathrm{O}(t=2 \mathrm{~s})$; the pressures of $\mathrm{CO}$ and $\mathrm{N}_{2} \mathrm{O}$ in each case are $8 \times 10^{-7} \mathrm{~Pa}$. The relative intensities of $\mathrm{AlVO}_{4}^{+}$and $\mathrm{AlVO}_{3}{ }^{+}$with increasing reaction times are shown in "b" and "d", respectively (adapted from Ref. [75])

with background impurities e.g. hydrogen-atom abstraction from water or residual hydrocarbons [75, 76].

Insight in the actual mechanism and in particular the question of the active site in the heteronuclear $\mathrm{AlVO}_{4}{ }^{+}$ cluster is provided by DFT calculations [75]. As shown in Fig. 5, the uncatalyzed reaction via transition state TS1 is much too high in energy to play a role at ambient conditions. In contrast, the catalytic conversion, which takes place at the doublet ground state of $\mathrm{AlVO}_{4}{ }^{+}$, commences by an initial, barrier-free binding of the carbon atom of $\mathrm{CO}$ to the radical oxygen atom of the $\mathrm{Al}-\mathrm{O}_{\mathrm{t}}{ }^{-}$moiety to generate intermediate 1. This species is formed with an internal energy of $71.2 \mathrm{kcal} \mathrm{mol}^{-1}$ below the entrance channel; as the energy in an 'isolated' system cannot be dissipated to a heat bath, liberation of $\mathrm{CO}_{2}$ occurs spontaneously requiring only $28.9 \mathrm{kcal} \mathrm{mol}^{-1}$. The catalytic cycle is completed by re-oxidation of $\mathrm{AlVO}_{3}{ }^{+}$with $\mathrm{N}_{2} \mathrm{O}$; as shown in Fig. 5, this reaction is also straightforward without barriers exceeding the energy of the entrance channel. Interestingly, this highly efficient catalytic cycle of a redox couple cannot be promoted by the non-radical terminal oxygen atom of the $\mathrm{V}=\mathrm{O}_{\mathrm{t}}$ moiety of $\mathrm{AlVO}_{4}{ }^{+}$. Computational findings demonstrate that this pathway is kinetically and thermochemically much less favorable than the one commencing at the Al- $\mathrm{O}_{\mathrm{t}}^{\bullet}$ unit (Fig. 6). Thus, the combined experimental/ computational study reveals the existence and operation of an 'active site' already in a rather small heteronuclear cluster. The particular and crucial role of oxygen-centered radicals in various other bond-activation processes will be addressed in more detail in Section 4 [77]. With regard to $\mathrm{CO}$ oxidation, it may suffice to mention that also cationic 


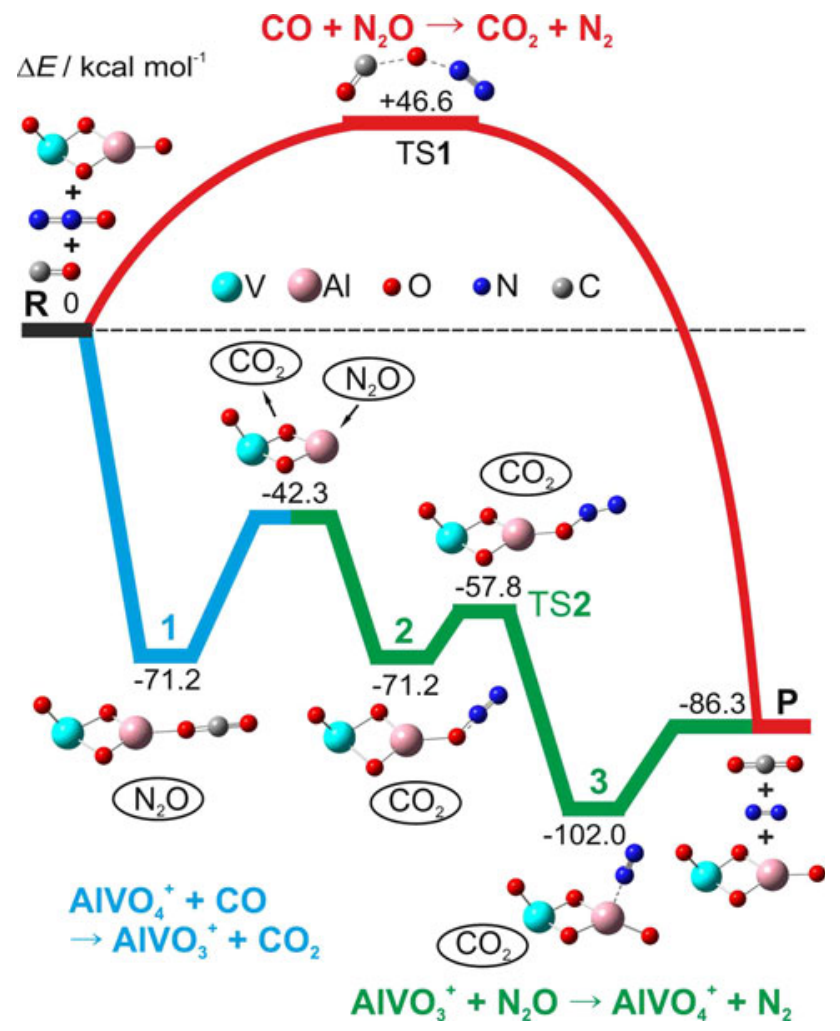

Fig. 5 Potential-energy surfaces (B3LYP/TZVP) for the oxidation of CO by $\mathrm{N}_{2} \mathrm{O}$ in the absence (red line) and the presence of $\mathrm{AlVO}_{4}{ }^{+}$(blue/green lines). The relative energies $\Delta E$ are given in $\mathrm{kcal} \mathrm{mol}^{-1}$ and corrected for zero point energy. The blue and green profiles correspond to the reaction of $\mathrm{AlVO}_{4}{ }^{+}$with $\mathrm{CO}$ and of $\mathrm{AlVO}_{3}{ }^{+}$with $\mathrm{N}_{2} \mathrm{O}$, respectively. TS transition structure; $\quad R=\mathrm{CO}+\mathrm{N}_{2} \mathrm{O}+\mathrm{AlVO}_{4}^{+} ; \quad P=\mathrm{CO}_{2}+\mathrm{N}_{2}+\mathrm{AlVO}_{4}{ }^{+}$ (adapted from Ref. [75])

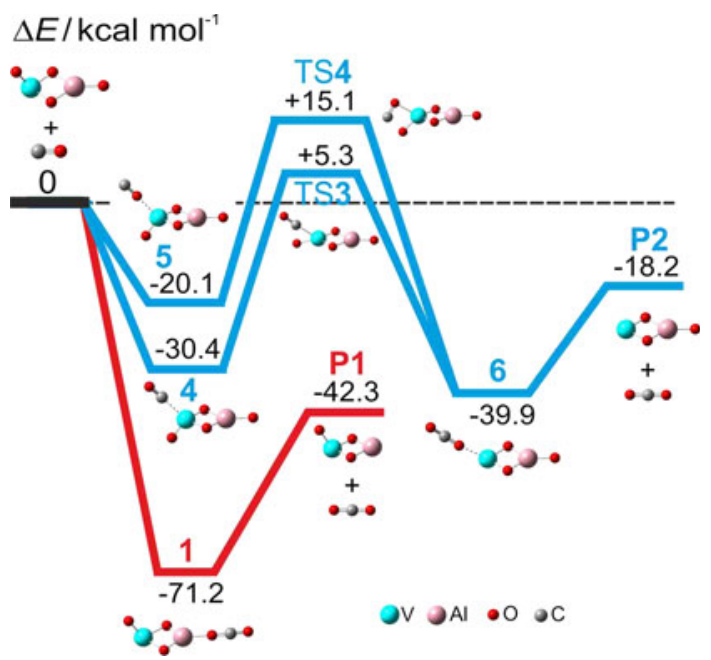

Fig. 6 The reaction $\left[\mathrm{O}_{\mathrm{t}} \mathrm{V}(\mu-\mathrm{O})_{2} \mathrm{AlO}_{\mathrm{t}}\right]^{+}+\mathrm{CO} \rightarrow\left[\mathrm{V}(\mu-\mathrm{O})_{2} \mathrm{AlO}_{\mathrm{t}}\right]^{+}+$ $\mathrm{CO}_{2}$ (blue lines) versus $\left[\mathrm{O}_{\mathrm{t}} \mathrm{V}(\mu-\mathrm{O})_{2} \mathrm{AlO}_{\mathrm{t}}\right]^{+}+\mathrm{CO} \rightarrow\left[\mathrm{O}_{\mathrm{t}} \mathrm{V}(\mu-\mathrm{O})_{2} \mathrm{Al}\right]^{+}+$ $\mathrm{CO}_{2}$ (red line) (adapted from Ref. [75])

clusters of the general composition $\left(\mathrm{ZrO}_{2}\right)_{n}{ }^{+}(n=2-5)$ as well as the anionic systems $\mathrm{Zr}_{n} \mathrm{O}_{2 n-1}^{-}(n=1-4)$ bring about room-temperature catalytic oxidation of $\mathrm{CO}$. Once again, it is a highly localized terminal oxygen radicalcenter which acts as the active site $[16,78]$.

In the context of catalytic, low-temperature $\mathrm{CO}$ oxidation, experimental and computational studies of free gold clusters occupy a central position in the literature [10-12, 25]. This is due to several factors: (1) Generally, the reactivity of a heterogeneous process is a complex convolution of the properties of metal cluster and those of the support. Therefore, the investigations of free, gas-phase clusters may help to reveal the intrinsic chemical features of an, e.g. nano-cluster catalyst. (2) Highly dispersed gold particles supported on metal oxides bring about low-temperature $\mathrm{CO}$ oxidation [79]; the catalytic activity correlates with the degree of dispersion, and $\mathrm{Au}_{8}$ clusters bound to oxygen-vacancy $\mathrm{F}$ center defects on $\operatorname{Mg}(001)$ were found to be the smallest clusters to mediate this reaction at low temperature [80]. (3) The reactivity of free gold cluster towards molecular oxygen, which is rightly considered as the ideal terminal oxidant, depends crucially on the charge state and the cluster size. While cationic gold clusters are completely inert toward $\mathrm{O}_{2}, \mathrm{Au}_{n}{ }^{-}$clusters react at room temperature and exhibit a notable odd/even alternation. For example, only cluster anions containing an even number of gold atoms (resulting in an odd number of valence electrons) were found to adsorb one $\mathrm{O}_{2}$ molecule $[10,81-83]$; this reactivity pattern corresponds with the odd/even variations of the vertical detachment energy showing minima for $\mathrm{Au}_{n}{ }^{-}(n=4,6,8, \ldots)$ [84]. Thus, the charge and size dependent electronic structures of the gold clusters fundamentally affect the chemical reactions with adsorbate molecules, and it was suggested that the interplay between gas-phase cluster physics and surface chemistry is a promising strategy to uncover "mechanisms of elementary steps in nanocatalysis" [85].

Next, some remarkable aspects pertinent to cooperative effects in the oxidation of $\mathrm{CO}$ with $\mathrm{O}_{2}$ will be presented. For excellent reviews on related topics, see Ref. $[8,10,12,16$, 22, 25]. In the context of Au-mediated catalytic $\mathrm{CO}$ oxidation by $\mathrm{O}_{2}$ notable effects have been observed when the gold clusters are exposed to both reactants, either simultaneously or sequentially. Although the same rules pertaining to individual $\mathrm{CO}$ or $\mathrm{O}_{2}$ adsorption continue to apply, the pre-adsorption of one reactant on a cluster may lead to an increased reactivity of the cluster to the other reactant. Thus, rather than competitive co-adsorption, the rare phenomenon of cooperative co-adsorption prevails. For example, experiments with mass-selected $\mathrm{Au}_{6}{ }^{-}$[86] (Fig. 7), or $\mathrm{Au}_{2}{ }^{-}[87,88]$ have demonstrated that this cooperative co-adsorption gives rise to the evaporation of $\mathrm{CO}_{2}$ in a truly catalytic cycle at room temperature or below.

A possible explanation for this enhancement of coadsorption activity occurring in an Eley-Rideal mechanism is that the first adsorbate affects the electronic structure of 


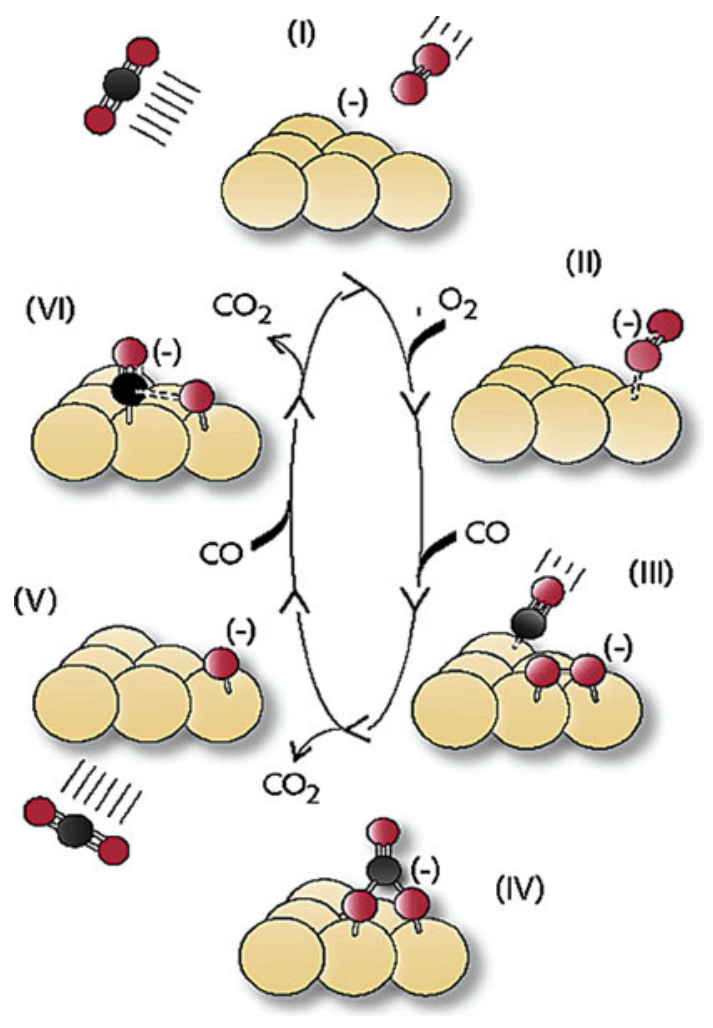

Fig. 7 Cooperative, thermal catalytic oxidations of $\mathrm{CO}$ to $\mathrm{CO}_{2}$ in the presence of $\mathrm{O}_{2}$ by the cluster anion $\mathrm{Au}_{6}{ }^{-}$(Au yellow, $\mathrm{C}$ black, $\mathrm{O}$ red). The free $\mathrm{Au}_{6}{ }^{-}$ion in its equilibrium structure (I) adsorbs $\mathrm{O}_{2}$ in its superoxide form (II); subsequent co-adsorption of $\mathrm{CO}$ may initially form an $\mathrm{Au}_{6} \mathrm{CO}_{3}{ }^{-}$species (III), which rearranges to the stable $\mathrm{CO}_{3}{ }^{-}$ adsorbate (IV); elimination of $\mathrm{CO}_{2}$ yields the $\mathrm{Au}_{6} \mathrm{O}^{-}$species (VI), from which a second $\mathrm{CO}_{2}$ molecule may be released and regenerate the $\mathrm{Au}_{6}{ }^{-}$catalyst. For the sake of clarity, the $\mathrm{Au}_{6}{ }^{-}$structure is depicted as retaining the same structure throughout the whole cycle (adapted from Ref. [86])

the cluster thus causing it to appear electronically different to the second approaching molecule. Accordingly, $\mathrm{CO}$ binds much more tightly to neutral $\mathrm{Au}_{n}$ than to $\mathrm{Au}_{n}{ }^{-}$ $(n=2,4,6, \ldots)$. Consequently, an Au cluster anion with a preadsorbed, one-electron acceptor $\mathrm{O}_{2}$ molecule will appear to be neutral to the approaching $\mathrm{CO}$ molecule because of the charge transfer that takes place from the $\mathrm{Au}_{n}{ }^{-}$cluster to the antibonding $2 \pi^{*}$ orbital of the $\mathrm{O}_{2}$ adsorbate. The analogy to the surface-catalyzed oxidation [89] of $\mathrm{CO}$ becomes clear in that the excess electron in $\mathrm{Au}_{n}{ }^{-}$is crucial for the reaction to occur, and the neutral supported clusters acquire this electron by charge transfer from the support. In the gas phase, a turnover frequency of approximately $100 \mathrm{CO}_{2}$ molecules per Au atom per second has been estimated [86] for the reaction catalyzed by $\mathrm{Au}_{n}{ }^{-}$ $(n=10)$. This efficiency is two(!) orders of magnitude greater than that observed for the commercial gold catalyst. Similar, temperature-dependent cooperative effects were reported for the $\mathrm{Au}_{3}{ }^{-} / \mathrm{CO} / \mathrm{O}_{2}$ system. While $\mathrm{Au}_{3}{ }^{-}$was found to be inert toward $\mathrm{O}_{2}$ in the temperature regime
100-200 K, pre-adsorption of $\mathrm{CO}$ resulted in a charge transfer from the metal cluster's HOMO into the $2 \pi^{*}$ antibonding orbital of $\mathrm{CO}$ [12]; this is accompanied with an isomerization of the $\mathrm{Au}_{3}{ }^{-}$cluster from a linear to a triangular geometry. As the latter exhibits a significantly lower electron detachment energy, charge transfer to $\mathrm{O}_{2}$ is possible resulting in the experimentally observed co-adsorption products $\mathrm{Au}_{3}(\mathrm{CO})\left(\mathrm{O}_{2}\right)_{2}{ }^{-}$[90].

Even cationic gold clusters which, in general, are inert toward molecular oxygen [81, 83, 91], can be activated by pre-adsorption of molecular hydrogen [91]. Molecular binding of $\mathrm{H}_{2}$ in for example $\mathrm{Au}_{4}\left(\mathrm{H}_{2}\right)_{4}{ }^{+}$brings about charge transfer from the $\mathrm{H}_{2}$ ligands to the $\mathrm{Au}_{4}{ }^{+}$core thus enabling the cluster to coadsorb $\mathrm{O}_{2}$ by donation of $0.14 e$ to the adsorbed $\mathrm{O}_{2}$ molecule. Similar effects were observed for $\mathrm{Au}_{n}{ }^{+}(n=2,16)$ [91], as well as for preoxidized $\mathrm{Pd}_{n}{ }^{+}$ clusters $(n=2-7)$ [92] or the oxides of both cationic and anionic gold cluster ions [93-95]. Once more, these (and other) examples clearly demonstrate that for the chemistry and physics of small cluster systems the motto holds true that "each atom counts!" [11].

\section{Oxygen-centered Radicals as Active Sites in Catalytic Hydrocarbon Activation}

Oxygen-centered radicals have been proposed to be responsible for the selective, large-scale heterogeneous oxidation of quite a few chemical compounds [96-98], and doping metal oxides, such as $\mathrm{MgO}$, with e.g. lithium to generate radical oxygen centers in bulk metal oxides may serve as an example [99]. As shown in the previous Section, the gas-phase metal-oxide mediated conversion $\mathrm{CO}$ $\rightarrow \mathrm{CO}_{2}$ is strongly affected by the presence or absence of these active sites. Here, the focus will be on two other elementary processes, i.e. (i) hydrogen-atom transfer (HAT) from methane, Eq. (3) [77, 100, 101], and (ii) oxygen-atom transfer (OAT) from metal-oxide clusters to ethene or ethyne, Eq. (4).

$$
\begin{aligned}
& \mathrm{CH}_{4}+\mathrm{MO} \rightarrow \mathrm{CH}_{3}+\mathrm{MO}-\mathrm{H} \\
& \left\{\mathrm{M}_{n} \mathrm{O}_{m}\right\}^{+/-}+\mathrm{C}_{2} \mathrm{H}_{2,4} \rightarrow\left\{\mathrm{M}_{n} \mathrm{O}_{m-1}\right\}^{+/-}+\mathrm{C}_{2} \mathrm{H}_{2,4} \mathrm{O}
\end{aligned}
$$

Regarding the mechanistic details of the gas-phase HAT reaction, two variants have been reported. The direct HAT process is operative predominantly for cationic open-shell oxide clusters with metal centers in relatively high oxidation states and with coordination numbers that prevent the indirect pathway from occurring. Examples showing this pattern include the non-metal system $\mathrm{SO}_{2}{ }^{\bullet+}$ [102], as well as the metal-containing clusters $\mathrm{Ce}_{2} \mathrm{O}_{4}{ }^{\bullet+}$ [103], $\mathrm{V}_{n} \mathrm{P}_{4-n} \mathrm{O}_{10}{ }^{\bullet+}(n=0,2-4)$ [104-106], $\left(\mathrm{Al}_{2} \mathrm{O}_{3}\right)_{n}{ }^{\bullet+}$ 
$(n=3-5)$ [107], $\mathrm{VAlO}_{4}{ }^{\bullet+}$ [76], or $\left(\mathrm{V}_{2} \mathrm{O}_{5}\right)_{n}\left(\mathrm{SiO}_{2}\right)_{m}^{\bullet+}$ ( $n=1,2 ; m=1-4)$ [108]. The polynuclear cluster $\mathrm{V}_{4} \mathrm{O}_{10}{ }^{\bullet+}$ was studied in great detail [104], showing that the rather efficient reaction proceeds barrier-free without the formation of a long-lived intermediate (Fig. 8).

The indirect, metal-mediated HAT is generally limited to small, often diatomic metal oxides, such as $\mathrm{MnO}^{+}$[109], $\mathrm{FeO}^{+}$[110], $\mathrm{MgO}^{+}$[111], $\mathrm{PbO}^{+}$[112], $\mathrm{CuO}^{+}$[113], $\mathrm{SnO}^{+}$ [114], $\mathrm{GeO}^{+}$[114], $\mathrm{CaO}^{+}[115], \mathrm{SrO}^{+}$[115], or $\mathrm{BaO}^{+}$ [115]. These systems have a vacant coordination site at the metal atom; thus, an encounter complex $\left[\mathrm{CH}_{4} \ldots \mathrm{M}-\mathrm{O}^{\bullet}\right]^{+}$as well as an intermediate $\left[\mathrm{CH}_{3}-\mathrm{M}-\mathrm{OH}\right]^{+}$are generated. The $\mathrm{MgO}^{\bullet+} / \mathrm{CH}_{4}$ couple serves as a good example, Fig. 9 [111]. The initially formed encounter complex has enough internal energy to rearrange the hydrocarbon part towards the reactive oxo site at which HAT occurs. Subsequently, in a metal-controlled fashion, the methyl group returns back to give the linear $\left[\mathrm{CH}_{3}-\mathrm{Mg}-\mathrm{OH}\right]^{+}$intermediate, from which $\mathrm{CH}_{3}{ }^{\bullet}$ is expelled. In general, while direct HAT resembles reaction patterns that prevail at surfaces, the indirect variant is closer to enzyme-mediated homolytic $\mathrm{C}-\mathrm{H}$ bond activation.
The crucial role of a high spin density at an oxygen atom to which the hydrogen is transferred, as explained in a quite general way by state-of-the-art quantum chemical calculations [101] and verified by numerous experimental studies [77], is nicely demonstrated by main-group aluminum-oxide clusters, which bring about efficient $\mathrm{C}-\mathrm{H}$ bond scission of methane at room temperature [107]: Only those clusters having an even number of aluminum atoms $\left(\mathrm{Al}_{2} \mathrm{O}_{3}\right)_{n}^{\bullet+}(n=3-5)$ are reactive, for example $\mathrm{Al}_{8} \mathrm{O}_{12}{ }^{\bullet+}$; in contrast, clusters with an odd number of aluminum atoms do not react at all with $\mathrm{CH}_{4}$, as for example $\mathrm{Al}_{7} \mathrm{O}_{11}{ }^{+}$. As shown in Fig. 10, in the doublet ground-state of $\mathrm{Al}_{8} \mathrm{O}_{12}{ }^{\bullet+}$ the spin is exclusively localized at one terminal oxygen atom, while in the triplet ground-state of $\mathrm{Al}_{7} \mathrm{O}_{11}{ }^{+}$ the spin is distributed among four bridging oxygen atoms. The consequences of these electronic features for the reactions of the two clusters with $\mathrm{CH}_{4}$ become obvious upon inspection of the respective potential-energy surfaces (Fig. 11). For the $\mathrm{Al}_{8} \mathrm{O}_{12}{ }^{\bullet+} / \mathrm{CH}_{4}$ couple a direct, barrierfree HAT results; in contrast, HAT to an oxygen atom of $\mathrm{Al}_{7} \mathrm{O}_{11}{ }^{+}$is not favored kinetically, and the significant barrier for the HAT results from the promotion energy to
Fig. 8 MD simulation showing the evolution of the potential energy (in kcal mol${ }^{-1}$ ) and the relevant bond lengths (in $\AA$ ) ( green $\mathrm{V}$, red $\mathrm{O}$ ) for the thermal reaction of $\mathrm{V}_{4} \mathrm{O}_{10}{ }^{\bullet+}$ with methane. The energy is shown in black, $d(\mathrm{C}-\mathrm{H})$ in blue, $d(\mathrm{O}-$ $\mathrm{H})$ in red, and $d(\mathrm{~V}-\mathrm{C})$ in green. The fluctuations after $450 \mathrm{fs}$ result from vibrational motions, mainly of the $\mathrm{OH}$ group. The blue isosurface indicates the spin density within the respective intermediate (adapted from Ref. [77])

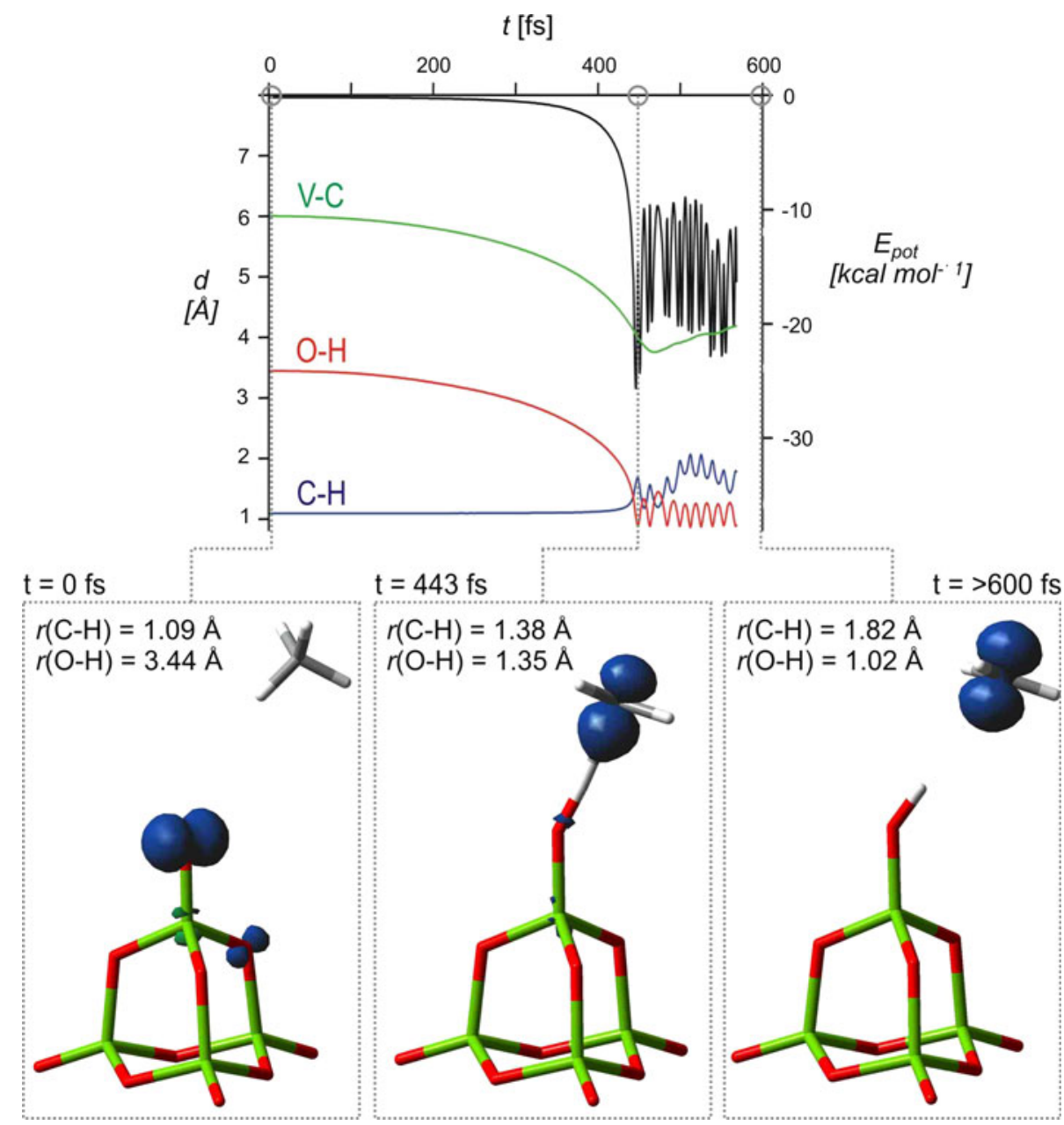


Fig. 9 Potential-energy surfaces (in kcal mol${ }^{-1}$ ) for the reaction of $\mathrm{MgO}^{+}$with $\mathrm{CH}_{4}$ calculated at the MP2/6$311+\mathrm{G}(2 \mathrm{~d}, 2 \mathrm{p})$ level of theory; selected bond lengths are given in $\AA$. The encircled structures depict the rearrangements occurring along the reaction coordinate (adapted from Ref. [111])

Fig. 10 Lowest-lying structures of doublet ground-state of $\mathrm{Al}_{8} \mathrm{O}_{12}{ }^{\bullet+}$ (a) and triplet groundstate of $\mathrm{Al}_{7} \mathrm{O}_{11}{ }^{+}(\mathbf{b})$, derived from DFT/UB2LYP calculations (gray $\mathrm{Al}$, red $\mathrm{O}$ ). The spin density is indicated by the blue isosurface (adapted from Ref. [77])
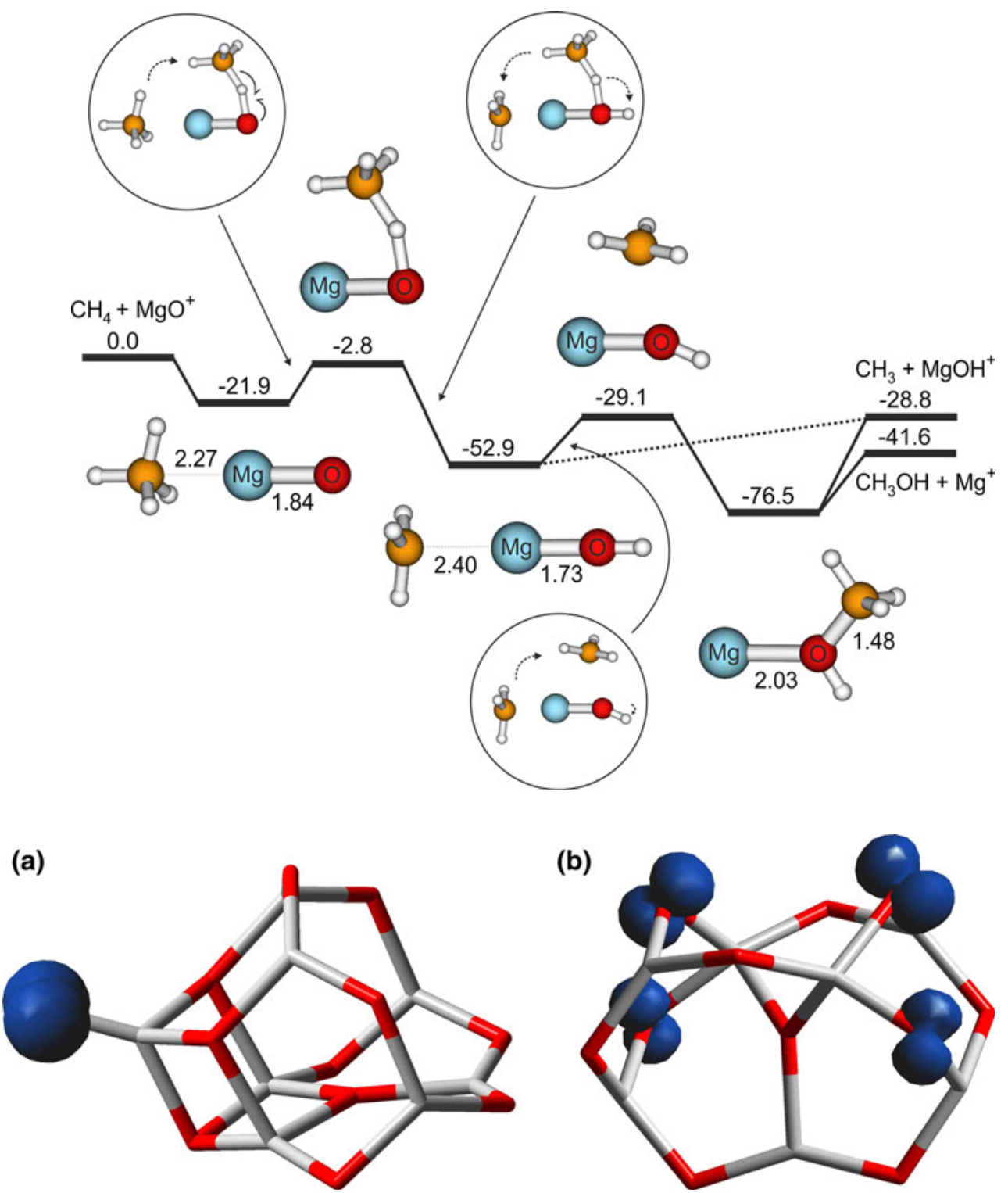

prepare a state which is capable to homolytically cleave the $\mathrm{C}-\mathrm{H}$ bond [77, 101]. Efficient intracluster spin-transfer in homonuclear $\mathrm{P}_{4} \mathrm{O}_{10}{ }^{\bullet+}$ and $\mathrm{V}_{4} \mathrm{O}_{10}{ }^{\bullet+}$ and barriers associated with this "preparation" step for the heteronuclear $\mathrm{V}_{3} \mathrm{PO}_{10}{ }^{\bullet+}$ system have been suggested as origin of the quite different reaction efficiencies of these two classes of structurally related clusters in their HAT reactions with $\mathrm{CH}_{4}$ [116].

With regard to OAT to $\mathrm{C}_{2} \mathrm{H}_{2,4}$, Eq. (4), combined experimental/computational studies on the $\left(\mathrm{ZrO}_{2}\right)_{n}{ }^{+}$ $(n=1-4) / \mathrm{C}_{2} \mathrm{H}_{2,4}$ systems $[16,78]$ also demonstrated the particular role that oxygen-centered radicals play. All these clusters exhibit a high spin density at a terminal oxygen atom and they bring about OAT-reactivity. As shown for the couple $\mathrm{ZrO}_{2}{ }^{+} / \mathrm{C}_{2} \mathrm{H}_{4}$ (Fig. 12), the reaction commences with the formation of a $\mathrm{C}-\mathrm{O}$ bond to be followed by an intramolecular hydrogen migration. It is this very step, that is crucial for the eventual release of acetaldehyde. The catalytic cycle is closed by an efficient reoxidation of $\mathrm{ZrO}^{+}$ with $\mathrm{N}_{2} \mathrm{O}$; a similar mechanistic scenario holds true for the reaction of these cluster cations with $\mathrm{C}_{2} \mathrm{H}_{2}$ to generate ketene $\left(\mathrm{CH}_{2} \mathrm{CO}\right)$. Finally, in line with condensed-phase studies [117], gas-phase oxidation of $\mathrm{C}_{2} \mathrm{H}_{4}$ with various vanadium-oxide cluster cations also gives rise to $\mathrm{CH}_{3} \mathrm{CHO}$ [118].

In contrast to the cationic $\left(\mathrm{ZrO}_{2}\right)_{n}^{+}(n=1-4)$ clusters, in the reactions of $\mathrm{C}_{2} \mathrm{H}_{4}$ and $\mathrm{C}_{2} \mathrm{H}_{2}$ with the anionic clusters $\mathrm{Zr}_{n} \mathrm{O}_{2 n+1}^{-}(n=1-4)$, association clearly dominates over OAT [16]. The reason is due to the fact that in the anionic systems on electrostatic grounds the nucleophilic hydrocarbons associate with the less coordinated, more electrophilic zirconium atom of e.g. $\mathrm{Zr}_{2} \mathrm{O}_{5}{ }^{-}$rather than to the 
Fig. 11 Potential-energy surfaces for the reactions of $\mathrm{Al}_{8} \mathrm{O}_{12}{ }^{\bullet+}$ (a) and $\mathrm{Al}_{7} \mathrm{O}_{11}{ }^{+}$ (b) with $\mathrm{CH}_{4}$ and the associated structures of the intermediates and transition structures, obtained at the UB3LYP/TZVP level of theory. Relative energies, corrected for zeropoint energy contributions, are given in $\mathrm{kcal} \mathrm{mol}^{-1}$ (adapted from Ref. [77])

Fig. 12 B3LYP-derived PES for the reaction of $\mathrm{ZrO}_{2}{ }^{\bullet+}$ with $\mathrm{C}_{2} \mathrm{H}_{4}$ and snapshots based on MD simulations. Relative energies are given in $\mathrm{kcal} \mathrm{mol}^{-1}$, and the time scale for the reaction in fs (adapted from Ref. [78]) (a)

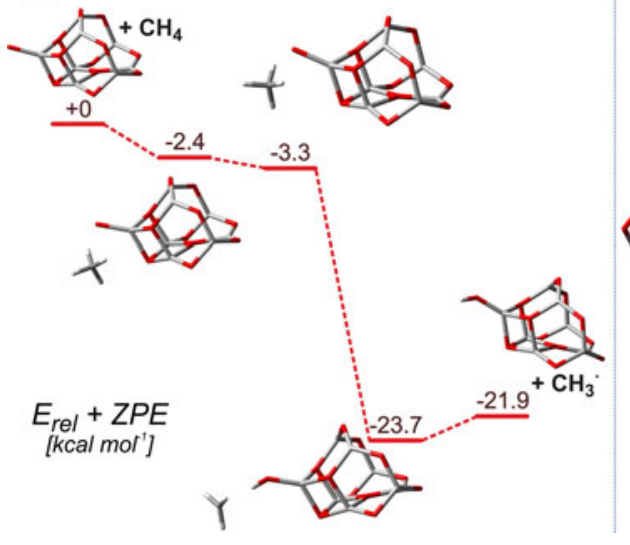

(b)<smiles>[V]</smiles>

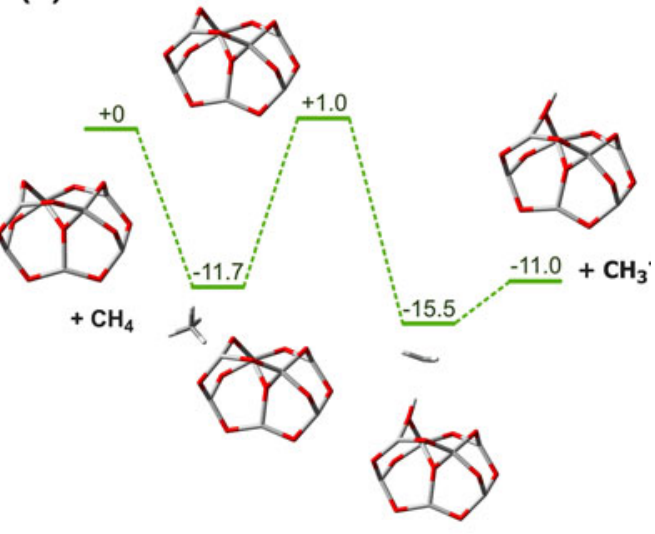

(a)
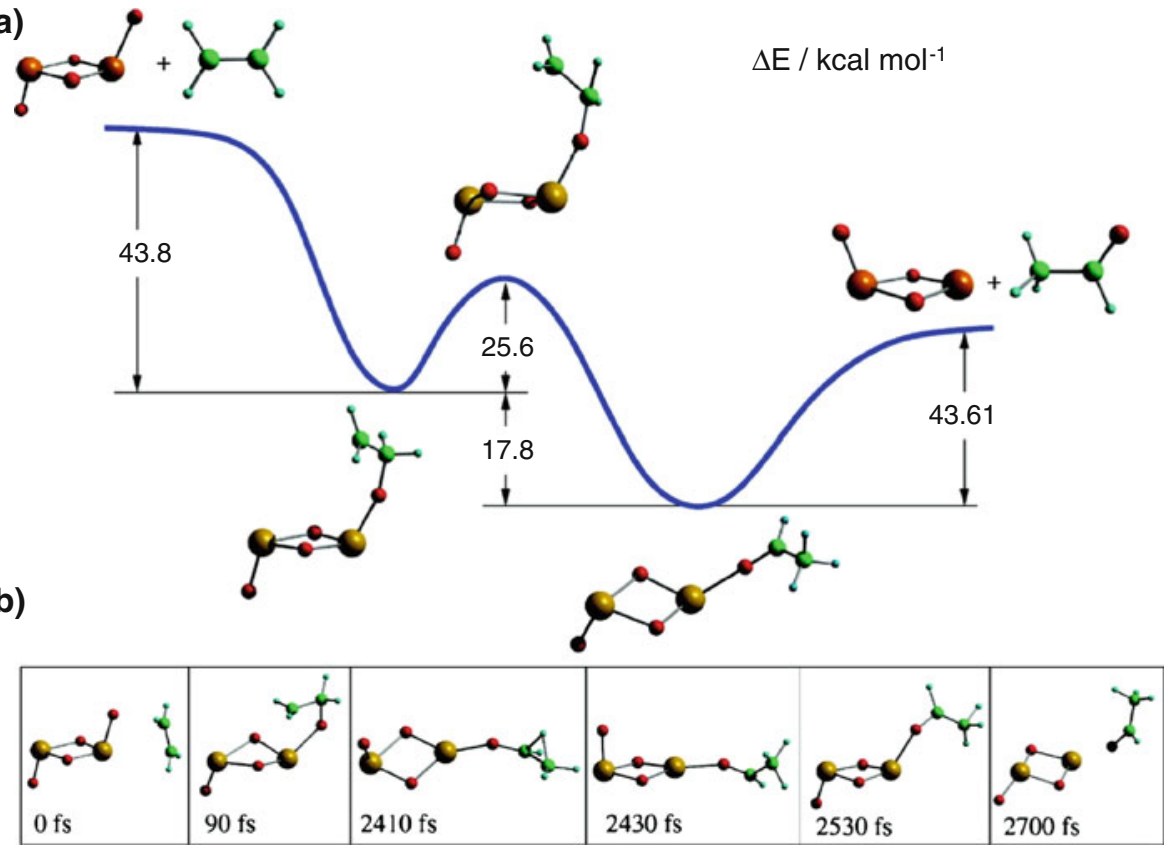
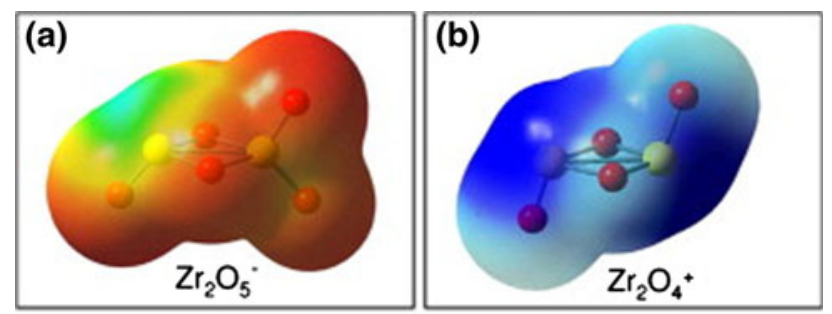

$-0.173$

0.173

Fig. 13 Molecular electrostatic potentials for $\mathbf{a} \mathrm{Zr}_{2} \mathrm{O}_{5}{ }^{-}$and $\mathbf{b} \mathrm{Zr}_{2} \mathrm{O}_{4}{ }^{+}$ (adapted from Ref. [16])

oxygen radical center being located on the opposite side of the cluster (Fig. 13). Dissociation of the strong zirconiumcarbon bond and migration of a peripheral oxygen-atom to a bridging position between the two zirconium centers requires an energy well above the entrance channel, as shown in Fig. 14 for the $\mathrm{Zr}_{2} \mathrm{O}_{5}{ }^{-} / \mathrm{C}_{2} \mathrm{H}_{2}$ system, and is thus not accessible at ambient conditions. Consequently, oxidation of the olefin is prevented.

\section{Mechanistic Aspects of Catalytic $\mathrm{CH}_{3} \mathrm{OH} \rightarrow \mathrm{CH}_{2} \mathrm{O}$ Conversion}

In the mechanistic understanding of the industrially important $\mathrm{CH}_{3} \mathrm{OH} \rightarrow \mathrm{CH}_{2} \mathrm{O}$ oxidation, some of the relevant questions center around the following topics: (i) In the initial step (Fig. 15), does a metal-based mediator [M] induce preferentially a cleavage of the stronger $\mathrm{O}-\mathrm{H}$ bond $\left(102.4 \mathrm{kcal} \mathrm{mol}^{-1}\right)$ or the weaker $\mathrm{C}-\mathrm{H}$ bond $(91.7 \mathrm{kcal}$ $\mathrm{mol}^{-1}$ ) of $\mathrm{CH}_{3} \mathrm{OH}$, and (ii) for a given sequence of events, which of the two hydrogen-transfer steps constitutes the ratelimiting one? As these questions have been dealt with quite 
Fig. 14 B3LYP-derived PES for the reaction of $\mathrm{Zr}_{2} \mathrm{O}_{5}{ }^{-}$with $\mathrm{C}_{2} \mathrm{H}_{2}$. Relative energies are given in $\mathrm{kcal} \mathrm{mol}^{-1}$ (adapted from Ref. [16])

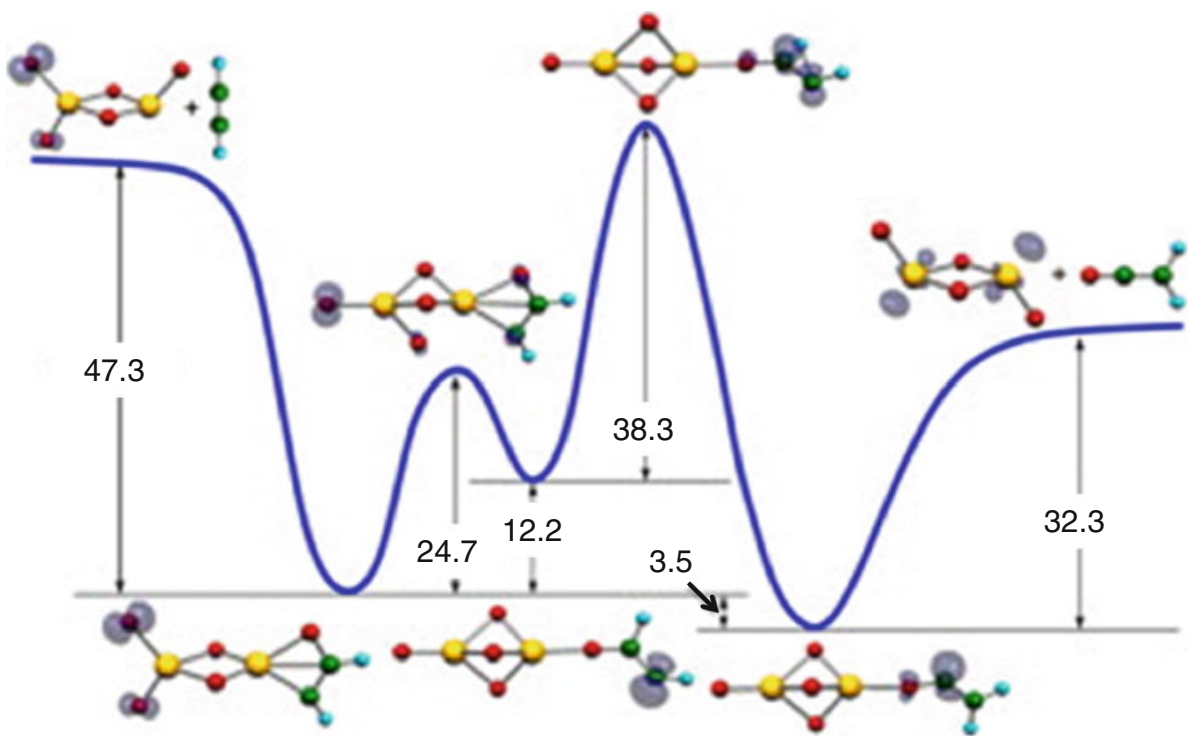

Recently, it was observed that not only the nature of the comprehensively in a recent review [20], here we will mention briefly only a few examples which demonstrate the rather unique role that the metal species and the ligands attached to them play in this seemingly simple reaction.

As shown in Fig. 16 and supported by additional experiments as well as extensive DFT-based calculations $[119,120]$, electrospray-ionization (ESI) of methanolic solutions of $\mathrm{MX}_{2}(\mathrm{M}=\mathrm{Fe}, \mathrm{Co}, \mathrm{Ni} ; \mathrm{X}=\mathrm{Br}$, I) brings about exclusive activation of the $\mathrm{O}-\mathrm{H}$ bond for iron to produce $\mathrm{Fe}\left(\mathrm{OCH}_{3}\right)^{+}$while the nickel precursor specifically cleaves the $\mathrm{C}-\mathrm{H}$ bond resulting in the formation of $\mathrm{Ni}\left(\mathrm{CH}_{2} \mathrm{OH}\right)^{+}$. For the cobalt system, one encounters an intermediate situation with a slight preference for the generation of the methoxy complex $\mathrm{Co}\left(\mathrm{OCH}_{3}\right)^{+}$in competition with generating $\mathrm{Co}\left(\mathrm{CH}_{2} \mathrm{OH}\right)^{+}$.

This metal-dependent selectivity of $\mathrm{O}-\mathrm{H}$ versus $\mathrm{C}-\mathrm{H}$ bond activation of $\mathrm{CH}_{3} \mathrm{OH}$ has its origin in the genesis by which the precursor species are formed. For iron, in the initial step a $\mathrm{Fe}\left(\mathrm{OCH}_{3}\right)\left(\mathrm{CH}_{3} \mathrm{OH}\right)_{n}{ }^{+}(n \leq 8)$ cluster is generated via solvolysis of $\mathrm{FeX}_{2}$ by the nucleophilic solvent $\mathrm{CH}_{3} \mathrm{OH}$. For the co-generation of isomeric $\left[\mathrm{Co}, \mathrm{C}, \mathrm{H}_{3}, \mathrm{O}\right]^{+}$, two pathways have been identified. The one, resulting in the $\mathrm{Co}\left(\mathrm{OCH}_{3}\right)^{+}$complex, is analogous to that for the iron system starting from $\mathrm{Co}\left(\mathrm{OCH}_{3}\right)$ $\left(\mathrm{CH}_{3} \mathrm{OH}\right)_{n}{ }^{+}(n=\leq 8)$. However, this precursor, in competition with sequential $\mathrm{CH}_{3} \mathrm{OH}$ evaporation, undergoes loss of $\mathrm{CH}_{2} \mathrm{O}$ to generate $\mathrm{Co}(\mathrm{H})\left(\mathrm{CH}_{3} \mathrm{OH}\right)^{+}$. This intermediate, in a spin-allowed elimination involving the $\mathrm{Co}-\mathrm{H}$ bond and a hydrogen atom from the methyl group of the $\mathrm{CH}_{3} \mathrm{OH}$ ligand, then decomposes to $\mathrm{H}_{2}$ and $\mathrm{Co}\left(\mathrm{CH}_{2} \mathrm{OH}\right)^{+}$. For the exclusive generation of $\mathrm{Ni}\left(\mathrm{CH}_{2} \mathrm{OH}\right)^{+}$, two pathways are operative, both involving $\mathrm{NiX}\left(\mathrm{CH}_{3} \mathrm{OH}\right)^{+}$ $(\mathrm{X}=\mathrm{H}, \mathrm{Br}$ ) as precursors; in the subsequent evaporation of $\mathrm{HX}$, based on labeling experiments, the hydrogen atom originates specifically from the methyl group of $\mathrm{CH}_{3} \mathrm{OH}$. metal, but also the ligand $\mathrm{L}$ for a given metal $\mathrm{M}$ matters with regard to the course of competitive $\mathrm{C}-\mathrm{H}$ versus $\mathrm{O}-\mathrm{H}$ bond activation (Schlangen $\mathrm{M}$, unpublished results). For example, the system $\mathrm{Ni}(\mathrm{OH})\left(\mathrm{CD}_{3} \mathrm{OH}\right)^{+}$gives rise to the formation of $\mathrm{H}_{2} \mathrm{O} / \mathrm{HDO}$ in a ratio 33:1, for the electronically related complex $\mathrm{Ni}(\mathrm{Cl})\left(\mathrm{CD}_{3} \mathrm{OH}\right)^{+}$the ratio $\mathrm{HCl} / \mathrm{DCl}$ drops to 2:1, for $\mathrm{Ni}(\mathrm{Br})\left(\mathrm{CD}_{3} \mathrm{OH}\right)^{+} \mathrm{HBr} / \mathrm{DBr}$ loss amounts to only $<0.05$, and, finally, the celebrated $\mathrm{Ni}(\mathrm{H})(\mathrm{OH})^{+}$ species $[121,122]$ in its reaction with $\mathrm{CD}_{3} \mathrm{OH}$ undergoes exclusive elimination of $\mathrm{HD}$, thus pointing to clean activation of the methyl $\mathrm{C}-\mathrm{D}$ bond (Schlangen $\mathrm{M}$, unpublished results). Clearly, these puzzling experimental findings constitute a challenge for computational chemistry to account for a highly metal- and ligand-dependent behavior.

Among the many examples of genuine catalytic cycles in the gas-phase oxidation of methanol $[8,11,19,20,123-$ 127], the system depicted in Fig. 17 is of particular mechanistic interest.

For both cycles the anionic complex $\mathrm{Mo}_{2}\left(\mathrm{O}_{6}\right)\left(\mathrm{OCHR}_{2}\right)^{-}$ $(\mathrm{R}=\mathrm{H}$, alkyl) serves as central intermediate [128], and three elementary steps matter: (1) condensation of the complex with the alcohols $\mathrm{R}_{2} \mathrm{CHOH}$ and elimination of $\mathrm{H}_{2} \mathrm{O}$ to produce an alkoxo-bound cluster; (2) oxidation of the alkoxo ligand and its liberation as an aldehyde or a ketone in a step which is rate-limiting and requires the supply of external energy through collision-induced dissociation; (3) regeneration of the catalyst by oxidation with nitromethane. The second cycle is similar, but differs in the order of the reaction with the alcohol and the use of nitromethane as the terminal oxidant.

The crucial role of the binuclear metal center in these redox processes was assessed by examination of the relative reactivities of the mononuclear $\mathrm{MO}_{3}(\mathrm{OH})^{-}$and binuclear $\mathrm{M}_{2} \mathrm{O}_{6}(\mathrm{OH})^{-}$complexes $(\mathrm{M}=\mathrm{Cr}$, Mo, W). The 
Fig. 15 Pathways for the metal-mediated methanolformaldehyde conversion

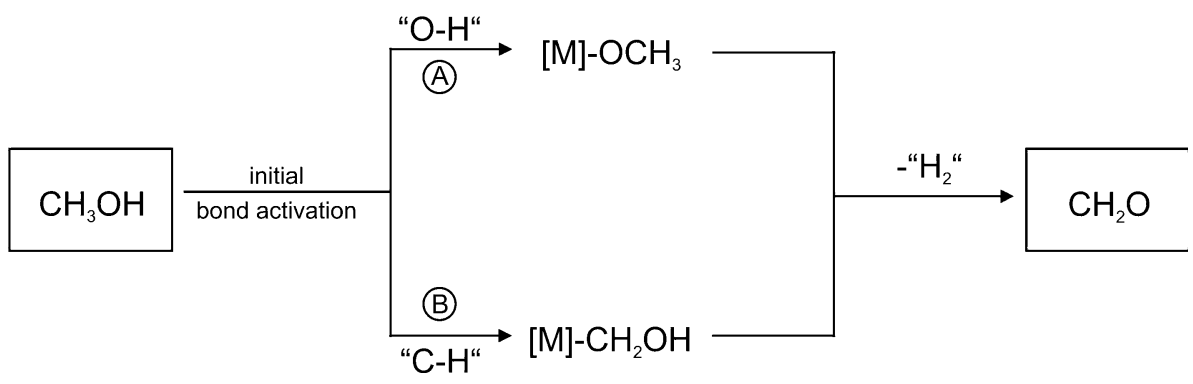

$\left[{ }^{56} \mathrm{Fe}, \mathrm{C}, \mathrm{H}_{3}, \mathrm{O}\right]^{+}$ $\mathrm{m} / \mathrm{z} 87$
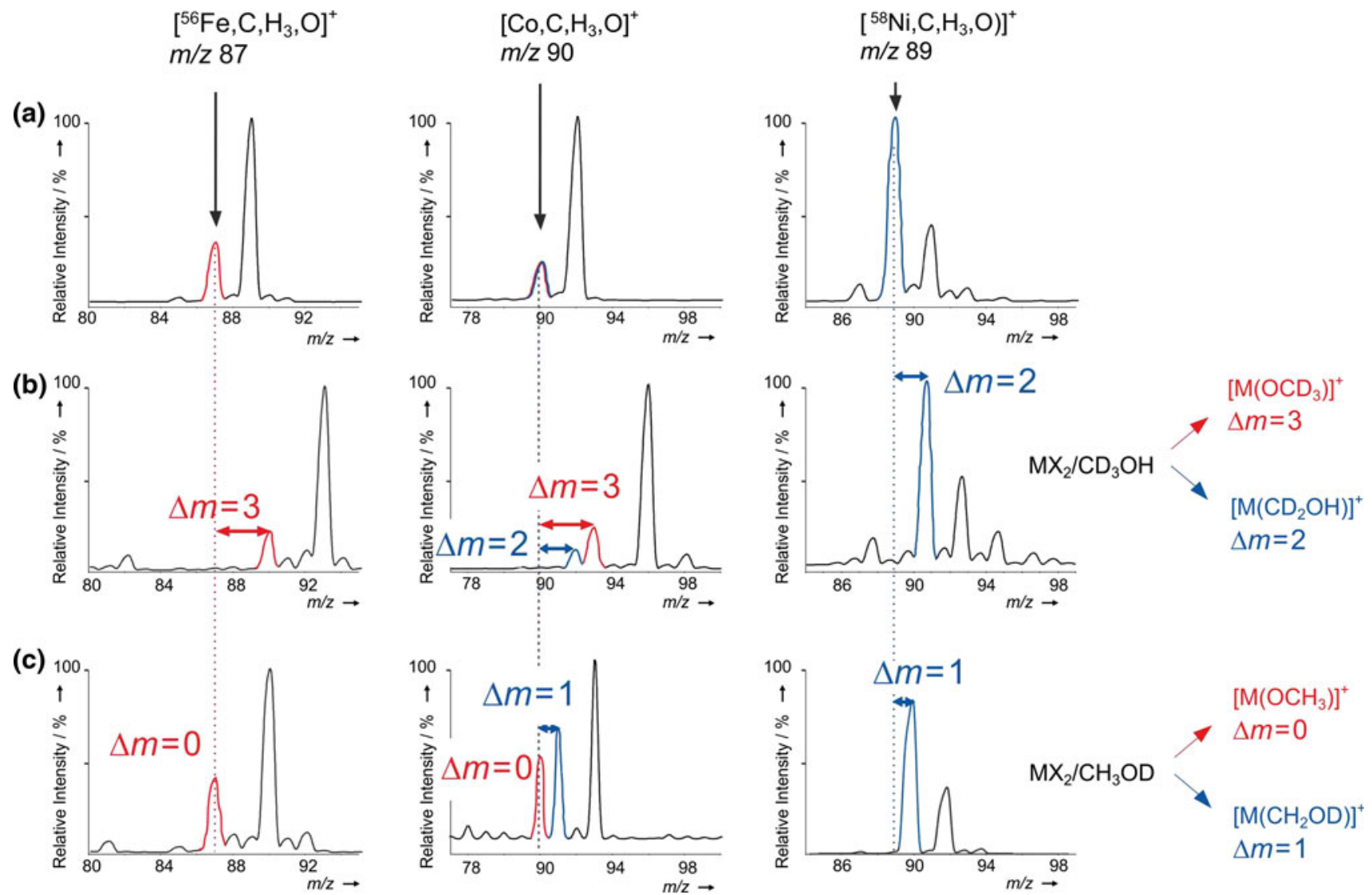

Fig. 16 Partial ESI mass spectra of the $\mathrm{Fe}, \mathrm{Co}$, and Ni halides $\mathrm{MX}_{2}\left(\mathrm{X}=\mathrm{Br}\right.$, I) dissolved in $\mathbf{a ~} \mathrm{CH}_{3} \mathrm{OH} / \mathrm{H}_{2} \mathrm{O}, \mathbf{b ~ C D}{ }_{3} \mathrm{OH} / \mathrm{H}_{2} \mathrm{O}$, and $\mathbf{c} \mathrm{CH} / \mathrm{OD} / \mathrm{D}_{2} \mathrm{O}$ (adapted from Ref. [119])

molybdenum and tungsten binuclear centers $(\mathrm{M}=\mathrm{Mo}, \mathrm{W})$ were reactive towards alcohols, but the chromium complex was not; this finding is consistent with the order of basicity of the hydroxo ligand in these anionic complexes. However, the tungsten complex $\mathrm{W}_{2} \mathrm{O}_{6}\left(\mathrm{OCHR}_{2}\right)^{-}$prefers a redox-neutral elimination of an alkene rather than oxidation of the alkoxo ligand to form an aldehyde or a ketone. This observation is in keeping with the oxidizing power of the anions. Interestingly, each of the mononuclear anions $\mathrm{MO}_{3}(\mathrm{OH})^{-}(\mathrm{M}=\mathrm{Cr}, \mathrm{Mo}, \mathrm{W})$ was inert to reaction with methanol, which highlights the importance of the second $\mathrm{MO}_{3}$ unit in the catalytic cycles. Clearly, only the bimolybdate center has the appropriate balance of electronic properties that allows it to participate in each of the three steps; these gas-phase studies with well-defined cluster anions correspond to the unique role of molybdenum(VI) trioxide $\left(\mathrm{MoO}_{3}\right)$ in the industrial oxidation of methanol to formaldehyde at $300-400{ }^{\circ} \mathrm{C}$ [129].

\section{Miscellaneous}

In addition to the topics addressed in this perspective there are numerous other examples for using gas-phase experiments with 'isolated' reagents as models for mimicking catalytic reactions in the condensed phase, and they include 
(a)

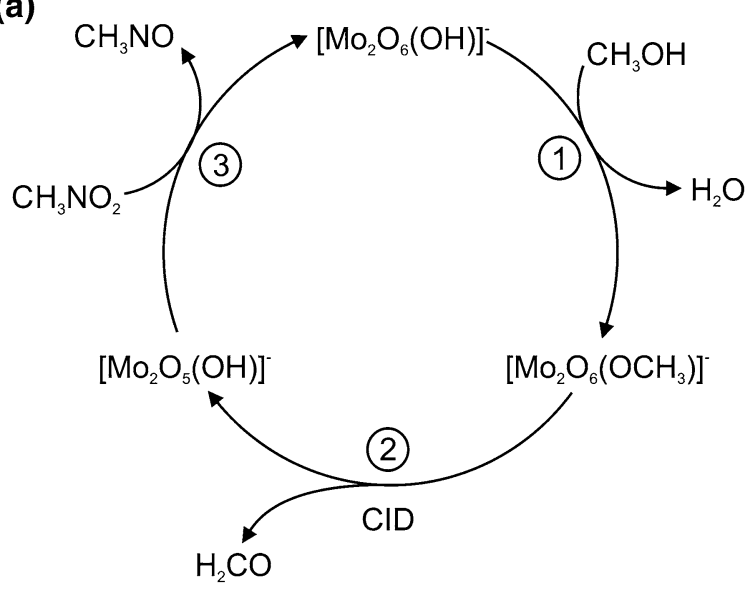

(b)

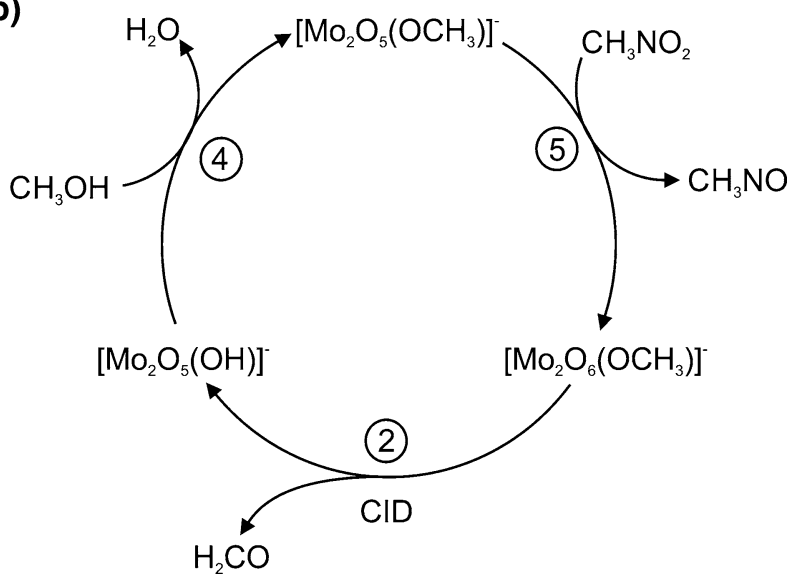

Fig. 17 a, b Gas-phase catalytic cycles for the oxidation of methanol to formaldehyde. Reaction (2) links $\mathrm{Mo}_{2} \mathrm{O}_{6}\left(\mathrm{OCH}_{3}\right)^{-}$and $\mathrm{Mo}_{2} \mathrm{O}_{5}(\mathrm{OH})^{-}$and appears in both cycles, which differ in the sequence of the reactions with $\mathrm{CH}_{3} \mathrm{NO}_{2}$ and $\mathrm{CH}_{3} \mathrm{OH}$ (adapted from Ref. [128])

inter alia: (1) the mechanistic understanding of the Cytochrome $\mathrm{P}-450$ mediated $\mathrm{C}-\mathrm{H}$ bond oxygenation [130-133] based on a detailed analysis of the most simple system, that is $\mathrm{FeO}^{+} / \mathrm{H}_{2}[134,135]$, (2) the relationship between the rich gas-phase chemistry of bare $\mathrm{PtO}_{2}{ }^{+}$[66] and the extraordinary features exhibited by high-valent platinum oxides [136], (3) the gas-phase $\mathrm{CH}_{4} \rightarrow \mathrm{CH}_{3} \mathrm{OH}$ or $\mathrm{C}_{6} \mathrm{H}_{6} \rightarrow$ $\mathrm{C}_{6} \mathrm{H}_{5} \mathrm{OH}$ conversions in fully thermal catalytic cycles [137, 138], (4) the efficient catalytic gas-phase dehydration of acetic acid to ketene [139], or (5) the elegant experimental/ computational gas-phase investigation on the reactions of bare $\mathrm{Ag}_{2} \mathrm{O}^{+}$with olefins which, in many ways, revealed crucial details of the large-scale heterogeneous olefin epoxidation [140].

There is indeed good reason to argue that an integrated approach employing the whole arsenal of seemingly esoteric gas-phase work in conjunction with appropriate computational studies will help to bridge the gap between chemistry and physics conducted at a strictly atomic level in the gas phase $[8,11,16,20,22,25]$ and the most complex behavior that prevails at surfaces [31, 32, 34, 89] or in solution [141, 142] and, at long last, may thus provide insight in the nature of active sites in catalysis.

Acknowledgments The work conducted at the TU Berlin has been generously funded by the Fonds der Chemischen Industrie and the Deutsche Forschungsgemeinschaft within the "Cluster of Excellence: Unifying Concepts in Catalysis". We are grateful to Andrea Beck for technical assistance.

Open Access This article is distributed under the terms of the Creative Commons Attribution License which permits any use, distribution, and reproduction in any medium, provided the original author(s) and the source are credited.

\section{References}

1. Kappes MM, Staley RH (1981) J Am Chem Soc 103:1286

2. Schröder D, Schwarz H (1995) Angew Chem Int Ed Engl 43:1973

3. Schwarz H, Schröder D (2000) Pure Appl Chem 72:2319

4. Ervin KM (2001) Int Rev Phys Chem 20:127

5. Armentrout PB (2001) Annu Rev Phys Chem 52:423

6. Mazurek U, Schwarz H (2003) J Chem Soc Chem Commun 1321

7. Chen P (2003) Angew Chem Int Ed 42:2832

8. O'Hair RAJ, Khairallah GN (2004) J Clust Sci 15:331

9. Schwarz H (2004) Int J Mass Spectrom 237:75

10. Kim YD (2004) Int J Mass Spectrom 238:17

11. Böhme DK, Schwarz H (2005) Angew Chem Int Ed 44:2336

12. Bernhardt TM (2005) Int J Mass Spectrom 243:1

13. Eberlin MN (2007) Eur J Mass Spectrom 13:19

14. Johnson GE, Tyo EC, Castleman AW Jr (2008) Proc Natl Acad Sci USA 105:18108

15. Schröder D, Schwarz H (2008) Proc Natl Acad Sci USA 105:18114

16. Johnson GE, Mitrić R, Bonačić-Koutecký V, Castleman AW Jr (2009) Chem Phys Lett 475:1

17. Schlangen M, Schwarz H (2009) Dalton Trans 10155

18. Roithová J, Schröder D (2009) Coord Chem Rev 253:66

19. Roithová J, Schröder D (2010) Chem Rev 110:1170

20. Schwarz H (2011) Angew Chem Int Ed 50:10096

21. Schlangen M, Schwarz H (2011) J Catal 284:126

22. Castleman AW Jr (2011) Catal Lett 141:1243

23. Kretschmer R, Schlangen M, Schwarz H (2012) Chem Eur J 18:40

24. Butschke B, Schwarz H (2012) Chem Sci 3:308

25. Lang S, Bernhardt TM (2012) Phys Chem Chem Phys 14:9255

26. Taylor HS (1925) Proc R Soc Lond A 108:105

27. Schwab GM, Pletsch E (1929) Z Phys Chem 131:385

28. Davis RJ (2003) Science 301:926

29. Horn K (2004) Science 205:483

30. Thomas JM, Raja R, Lewis DW (2005) Angew Chem Int Ed 44:6456

31. Somorjai GA, Park JY (2008) Angew Chem Int Ed 47:9212

32. Ertl G (2008) Angew Chem Int Ed 47:3524

33. Guo H, Wei J, Polanyi JC, Yang SY (2008) ACS Nano 2:699

34. Somorjai GA (2008) J Chem Phys 128:182504

35. Hasenberg D, Schmidt LD (1986) J Catal 97:156 
36. Diefenbach M, Brönstrup M, Aschi M, Schröder D, Schwarz H (1999) J Am Chem Soc 121:10614

37. Koszinowski K, Schröder D, Schwarz H (2004) Organometallics 23:1132

38. Horn R, Mestl G, Thiede M, Jentöft FC, Schmidt PM, Bewersdorf R, Weber R, Schlögl R (2004) Phys Chem Chem Phys 6:4514

39. Ertl G, Gloyna T (2003) Z Phys Chem 217:1207

40. Lautens M, Klute W, Tam W (1996) Chem Rev 96:49

41. Wörz AS, Judai K, Abbet S, Antonietti JM, Heiz U, DelVitto A, Giordano L, Pacchioni G (2004) Chem Phys Lett 399:266

42. Wesendrup R, Schwarz H (1997) Organometallics 16:461

43. Berg C, Kaiser S, Schindler T, Kronseder C, Niedner-Schatteburg G, Bondybey VE (1994) Chem Phys Lett 231:139

44. Heinemann C, Cornehl HH, Schwarz H (1995) J Organomet Chem 501:201

45. Schröder D, Sülzle D, Hrušák J, Böhme DK, Schwarz H (1991) Int J Mass Spectrom Ion Process 110:145

46. Baranov V, Becker H, Böhme DK (1997) J Phys Chem A 101:5137

47. Chrétien S, Salahub DR (2003) J Chem Phys 119:12299

48. Schnabel P, Irion MP, Weil KG (1991) J Phys Chem 95:9688

49. Schnabel P, Weil KG, Irion MP (1992) Angew Chem Int Ed Engl 31:636

50. Irion MP (1992) Int J Mass Spectrom Ion Process 121:1

51. Gehret O, Irion MP (1996) Chem Phys Lett 254:379

52. Duncan MA (2003) Int Rev Phys Chem 22:407

53. Lunsford JH (1995) Angew Chem Int Ed 34:970

54. Takanabe K, Iglesia E (2009) J Phys Chem C 113:10131

55. Lang SM, Bernhardt TM, Barnett RN, Landman U (2010) Angew Chem Int Ed Engl 49:980

56. Lang SM, Bernhardt TM (2011) Faraday Discuss 152:337

57. Lang SM, Bernhardt TM, Barnett RN, Landman U (2011) J Phys Chem C 115:6788

58. Li FX, Armentrout PB (2006) J Chem Phys 125:133114

59. Heinemann C, Wesendrup R, Schwarz H (1995) Chem Phys Lett 239:75

60. Achatz U, Berg C, Joos S, Fox BS, Beyer MK, Niedner-Schatteburg G, Bondybey VE (2000) Chem Phys Lett 320:52

61. Koszinowski K, Schröder D, Schwarz H (2003) J Phys Chem A 107:4999

62. Kummerlöwe G, Balteanu J, Sun Z, Balaj OP, Bondybey VE, Beyer MK (2006) Int J Mass Spectrom 254:183

63. Wang ZC, Dietl N, Kretschmer R, Ma JB, Weiske T, Schlangen M, Schwarz H (2012) Angew Chem Int Ed 51:3703

64. Blagojevic V, Orlova G, Bohme DK (2005) J Am Chem Soc 127:3345

65. Barcenov V, Javahery G, Hopkinson AC, Bohme DK (1995) J Am Chem Soc 117:12801

66. Brönstrup M, Schröder D, Kretzschmar I, Schwarz H, Harvey JN (2001) J Am Chem Soc 123:142

67. Koyanagi GK, Bohme DK (2001) J Phys Chem A 105:8964

68. Lavrov VV, Blagojevic V, Koyanagi GK, Orlova G, Bohme DK (2004) J Phys Chem A 108:5610

69. Kretzschmar I, Fiedler A, Harvey JN, Schröder D, Schwarz H (1997) J Phys Chem A 101:6252

70. Blagojevic V, Jarvis MJY, Flaim E, Koyanagi GK, Lavrov VV, Böhme DK (2003) Angew Chem Int Ed 42:4293

71. Balaj OP, Balteanu I, Roßteuscher TTJ, Beyer MK, Bondybey VE (2004) Angew Chem Int Ed 43:6519

72. Siu CK, Reitmeier SJ, Balteanu I, Bondybey VE, Beyer MK (2007) Eur Phys J D 43:189

73. Lv L, Wang YC, Jin Y (2011) Theor Chem Acc 130:15

74. Balteanu I, Balaj OP, Beyer MK, Bondybey VE (2004) Phys Chem Chem Phys 6:2910
75. Wang ZC, Dietl N, Kretschmer R, Weiske T, Schlangen M, Schwarz H (2011) Angew Chem Int Ed 50:12351

76. Wang ZC, Wu XN, Zhao YX, Ma JB, Ding XL, He SG (2010) Chem Phys Lett 489:25

77. Dietl N, Schlangen M, Schwarz H (2012) Angew Chem Int Ed 51:5544

78. Johnson GE, Mitrić R, Tyo EC, Bonačić-Koutecký V, Castleman AW Jr (2008) J Am Chem Soc 130:13912

79. Hutchings GJ (2011) Faraday discussions 152. Cardiff, UK

80. Yoon B, Häkkinen H, Landman U, Wörz AS, Antonietti JM, Abbet S, Judai K, Heiz U (2005) Science 307:403

81. Cox DM, Brickman R, Creegan K, Kaldor A (1991) Z Phys D: At, Mol Clusters 19:353

82. Lee T, Ervin KM (1994) J Phys Chem 98:10023

83. Koszinowski K, Schröder D, Schwarz H (2003) Chem Phys Chem 4:1233

84. Taylor KJ, Pettiette-Hall CL, Chesnovsky O, Smalley RE (1992) J Chem Phys 96:3319

85. Kim YD, Fischer M, Ganteför G (2003) Chem Phys Lett 377:170

86. Wallace WT, Whetten RL (2002) J Am Chem Soc 124:7499

87. Häkkinen H, Landman U (2001) J Am Chem Soc 123:9704

88. Socaciu LD, Hagen J, Bernhardt TM, Wöste L, Heiz U, Häkkinen H, Landman U (2003) J Am Chem Soc 125:10437

89. Freund HJ, Meijer G, Scheffler M, Schlögl R, Wolf M (2011) Angew Chem Int Ed 50:10064

90. Hagen J, Socaciu LD, Elijazyfer M, Heiz U, Bernhardt TM, Wöste L (2002) Phys Chem Chem Phys 4:1707

91. Lang SM, Bernhardt TM, Barnett RN, Yoon B, Landman U (2009) J Am Chem Soc 131:8939

92. Lang SM, Schnabel T, Bernhardt TM (2012) Phys Chem Chem Phys 14:9364

93. Kimble ML, Castleman AW Jr, Mitrić R, Bürgel C, BonačićKoutecký V (2004) J Am Chem Soc 126:2526

94. Kimble ML, Moore NA, Johnson GE, Castleman AW Jr, Bürgel C, Mitrić R, Bonačić-Koutecký V (2006) J Chem Phys 125:204311

95. Bürgel C, Reilly NM, Johnson GE, Mitrić R, Kimble ML, Castleman AW Jr, Bonačić-Koutecký V (2008) J Am Chem Soc 130:1694

96. Panov GI, Dubkov KA, Starokon EV (2006) Catal Today 117:148

97. Lunsford JH (2000) Catal Today 63:65

98. Jaro S, Godini HR, Arellano-Garcia H, Ornikhah M, Wozny G (2010) Chem Eng Sci 65:6341

99. Pacchioni G (2008) J Chem Phys 128:182505

100. Zhao YX, Wu XN, Ma JB, He SG, Ding XL (2011) Phys Chem Chem Phys 13:1925

101. Lai W, Li C, Chen H, Shaik S (2012) Angew Chem Int Ed 51:5556

102. de Petris G, Troiani A, Rosi M, Angelini G, Ursini O (2009) Chem Eur J 15:4248

103. Wu XN, Zhao YX, Xue W, Wang ZC, He SG, Ding XL (2010) Phys Chem Chem Phys 12:3984

104. Feyel S, Döbler J, Schröder D, Sauer J, Schwarz H (2006) Angew Chem Int Ed 45:4681

105. Dietl N, Engeser M, Schwarz H (2009) Angew Chem Int Ed 48:4861

106. Dietl N, Höckendorf RF, Schlangen M, Lerch M, Beyer MK, Schwarz H (2011) Angew Chem Int Ed 50:1430

107. Feyel S, Döbler J, Höckendorf R, Beyer MK, Sauer J, Schwarz H (2008) Angew Chem Int Ed 47:1946

108. Ding XL, Zhao YX, Wu XN, Wang ZC, Ma JB, He SG (2010) Chem Eur J 16:11463

109. Ryan MF, Fiedler A, Schröder D, Schwarz H (1995) J Am Chem Soc 117:2033 
110. Schröder D, Fiedler A, Hrušák J, Schwarz H (1992) J Am Chem Soc 114:1215

111. Schröder D, Roithová J (2006) Angew Chem Int Ed 45:5705

112. Zhang X, Schwarz H (2010) Chem Cat Chem 2:1391

113. Dietl N, van der Linde C, Schlangen M, Beyer MK, Schwarz H (2011) Angew Chem Int Ed 50:4966

114. Chen K, Wang ZC, Schlangen M, Wu YD, Zhang X, Schwarz H (2011) Chem Eur J 17:9619

115. Božović A, Bohme DK (2009) Phys Chem Chem Phys 11:5940

116. Ma JB, Wu XN, Zhao XX, Ding XL, He SG (2010) Phys Chem Chem Phys 12:12223

117. Oyama ST, Middlebrook T, Somorjai GA (1990) J Phys Chem 94:5029

118. Justes DR, Mitrić R, Moore NA, Bonačić-Koutecký V, Castleman AW Jr (2003) J Am Chem Soc 125:6289

119. Schlangen M, Schwarz H (2010) Chem Commun $46: 1878$

120. Schlangen M, Schwarz H (2010) Chem Cat Chem 2:799

121. Dede Y, Zhang X, Schlangen M, Schwarz H, Baik MH (2009) J Am Chem Soc 131:12634

122. Lackuntza O, Matxain JM, Ruipérez F, Besora M, Maseras F, Ugalde JM, Schlangen M, Schwarz H (2012) Phys Chem Chem Phys 14:9306

123. Waters T, Khairallah GN, Wimala SASY, Ang YC, O'Hair RAJ, Wedd AG (2006) Chem Commun 4503

124. Waters T, Wedd AG, O'Hair RAJ (2007) Chem Eur J 13:8818

125. Chiavarino B, Crestonie ME, Fornarini S (2002) Chem Eur J $8: 2740$

126. Routry K, Zhou W, Kiely CJ (2011) ACS Catal 1:54
127. Yin S, Bernstein ER (2012) Int J Mass Spectrom 321-322:49

128. Waters T, O'Hair RAJ, Wedd AG (2003) J Am Chem Soc $125: 3384$

129. Barteau MA (1996) Chem Rev 96:1413

130. Shaik S, de Visser SP, Ogliaro F, Schwarz H, Schröder D (2002) Curr Opin Chem Biol 6:556

131. Ye S, Neese F (2009) Curr Opin Chem Biol 13:89

132. Shaik S, Cohen S, Wang Y, Chen D, Kemmer D, Thiel W (2010) Chem Rev 110:949

133. Xue G, De Hont R, Münch E, Que L Jr (2010) Nat Chem 2:400

134. Shaik S, Danovich D, Fiedler A, Schröder D, Schwarz H (1995) Helv Chim Acta 78:1393

135. Schröder D, Schwarz H, Clemmer DE, Chen Y, Armentrout PB, Baranov VI, Bohme DK (1997) Int J Mass Spectrom Ion Process 161:175

136. Efremenko I, Poverenov E, Martin JML, Milstein D (2010) J Am Chem Soc 132:14886

137. Božović A, Feil A, Koyanagi GK, Viggiano AA, Zhang X, Schlangen M, Schwarz H, Bohme DK (2010) Chem Eur J 16:11605

138. Ryan MF, Stöckigt D, Schwarz H (1994) J Am Chem Soc 116:9565

139. Waters T, O’Hair RAJ, Wedd AG (2003) Int J Mass Spectrom 228:599

140. Roithová J, Schröder D (2007) J Am Chem Soc 129:15311

141. Agrawal D, Schröder D (2011) Organometallics 30:32

142. Schröder D (2012) Acc Chem Res. doi:10.1021/ar3000426 